\title{
Motivated monitoring by institutional investors and firm investment efficiency
}

Article

Accepted Version

Ward, C., Yin, C. and Zeng, Y. (2020) Motivated monitoring by institutional investors and firm investment efficiency. European Financial Management, 26 (2). pp. 348-385. ISSN 1468-036X doi: https://doi.org/10.1111/eufm.12232 Available at https://centaur.reading.ac.uk/84305/

It is advisable to refer to the publisher's version if you intend to cite from the work. See Guidance on citing.

To link to this article DOI: http://dx.doi.org/10.1111/eufm.12232

Publisher: Wiley

All outputs in CentAUR are protected by Intellectual Property Rights law, including copyright law. Copyright and IPR is retained by the creators or other copyright holders. Terms and conditions for use of this material are defined in the End User Agreement.

\section{www.reading.ac.uk/centaur}

\section{CentAUR}

Central Archive at the University of Reading

Reading's research outputs online 


\title{
Motivated Monitoring by Institutional Investors and Firm Investment Efficiency*
}

\author{
Charles Ward ${ }^{1}$, Chao Yin $^{1}$, and Yeqin Zeng ${ }^{\dagger 2}$ \\ ${ }^{1}$ ICMA Centre, Henley Business School, University of Reading, Reading, RG6 6BA, UK \\ ${ }^{2}$ Durham University Business School, Durham University, Durham, DH1 3LB, UK
}

\begin{abstract}
We find that motivated monitoring by institutional investors mitigates firm investment inefficiency, estimated by Richardson's (2006) approach. This relation is robust when using the annual reconstitution of the Russell indexes as exogenous shocks to institutional ownership during the period 1995-2015 and after classifying institutional ownership by institution type. We also show that closer monitoring mitigates the problem of both over-investing free cash flows and under-investment due to managers' career concerns. Finally, we document that the effectiveness of the monitoring by institutional investors appears to increase monotonically with respect to the firm's relative importance in their portfolios.
\end{abstract}

Keywords: Institutional investors; Investment efficiency; Monitoring attention; Agency problem; Index switch JEL classification: G23; G30; G31; M4

*We would like to thank the journal editor John Doukas, the two anonymous referees, Seth Armitage, Chris Brooks, Rong Ding, Lynn Hodgkinson, Mohammad Irani, Scott Richardson, Alessio Ruzza, Ben Sila, Lei Zhao, and seminar participants at the ICMA Centre, 2017 FEBS annual conference, 2017 EFMA annual conference, 2017 World Finance conference, 2017 AAA annual conference, and 2017 FMA annual conference for their insightful and constructive comments. The financial support from Durham University Business School and ICMA Centre is gratefully acknowledged.

${ }^{\dagger}$ Corresponding author: Associate Professor, Durham University Business School, Mill Hill Lane, Durham, DH1 3LB, United Kingdom. Tel. +44(0)1913345095. E-mail addresses: yeqin.zeng@durham .ac.uk (Y.Zeng), c.ward@icmacentre.ac.uk (C. Wards), chao.yin@icmacentre.ac.uk (C. Yin).

This article has been accepted for publication and undergone full peer review but has not been through the copyediting, typesetting, pagination and proofreading process, which may lead to differences between this version and the Version of Record. Please cite this article as doi:10.1111/eufm.12232

This article is protected by copyright. All rights reserved. 


\section{Introduction}

Successful investment by companies creates shareholder value and drives firm growth. However, firms may fail to invest efficiently due to conflicts of interest between managers and shareholders. Several managerial agency problems have been identified as leading to either over-investment (e.g., Jensen and Meckling, 1976; Shleifer and Vishny, 1997; Richardson, 2006) or under-investment (e.g., Porter, 1991; Bertrand and Mullainathan, 2003; Aghion et al., 2013). As less efficient investment is associated with lower firm future stock performance (Titman et al., 2004; Cai and Zhang, 2011), understanding the governance of firm investment efficiency in publicly traded companies is of great importance to firms' shareholders.

In this paper, we examine the role of motivated monitoring by institutional investors in improving corporate investment efficiency. Given the trade-off between the costs and benefits of active monitoring, institutional investors will not have the same incentive to monitor the activities of every firm in their portfolios. First, institutional investors are not homogeneous: their monitoring roles are related to institution type, their investment horizon, and their preference for trading (Bushee, 1998; Chen et al., 2007; Schmidt and Fahlenbrach, 2017). Second, it is not optimal for institutional investors to equally monitor all the firms held in their portfolios, because their capacity to monitor is not unlimited (Kempf et al., 2017) $;^{1}$ the motivation of institutional monitoring would rationally depend on the relative importance of an individual stock in their portfolios (Fich et al., 2015). Previous studies have focused on the heterogeneity of institutional investors, and how their institutional characteristics might affect firm performance. In contrast, we follow Fich et al. (2015) and focus on the variety of monitoring attention that would be expected within institutions on firms held in their portfolios, and how this divergence can affect managerial decision making.

When economic agents have a limited capacity for processing information, it is rational for them to vary the attention they give to different sources of information when making decisions (Sims, 2003). Based on the assumption of limited attention, Kacperczyk et al. (2016) develop an attention allocation model to predict optimal information choices for mutual funds. Kempf et al. (2017) find that an institutional investor's monitoring attention to the firms it holds may become distracted if an exogenous shock affects the stock returns of unrelated firms in its portfolio. Fich et al. (2015) posit that when an

\footnotetext{
${ }^{1}$ In practice, it is costly for investors to collect firm-specific information, analyze the information with professional expertise, monitor firm activities, and intervene through shareholder activism.
}

This article is protected by copyright. All rights reserved. 
institution has only limited monitoring attention, a greater proportion of its portfolio that is represented by a firm will be associated with greater benefits of monitoring that firm. They use the relative importance of a firm in institutional investors' portfolios as a proxy for the motivation of institutional monitoring in mergers and acquisitions (M\&As) and find that targets with more motivated monitoring institutional ownership (IO) have higher deal premiums and deal completion probabilities. ${ }^{2}$ Motivated by these studies, we measure an institutional investor's motivation to monitor a firm by the fraction of the institution's portfolio represented by the firm. If the optimal level of monitoring attention is determined by the trade-off between monitoring benefits and costs, an institutional investor will be more motivated to monitor firms which are relatively more important in its portfolio. ${ }^{3}$ We extend Fich et al.'s (2015) study to firms' general investment decisions and compare institutional investors with the highest motivation to monitor with those that potentially have the least motivation to monitor.

Using a large U.S. sample for the period 1995-2015, we measure inefficient investment as the abnormal investment estimated by Richardson's (2006) investment model. Firm over-investment (under-investment) is reflected in a positive (negative) regression residual. In addition to Richardson's (2006) single panel regression, we estimate inefficient investment in year $t$ by a historical panel regression from 1981 to year $t$. The historical panel regression method avoids using unknown future information to predict the current optimal level of investment. ${ }^{4}$ Our measure of institutional investors' monitoring motivation follows Fich et al. (2015). We sort all stocks into ten decile groups by their holding value weighting within each institutional portfolio. Institutional investors have the highest (least) motivation to monitor firms in the decile 1 (10) groups including stocks with the top (bottom) $10 \%$ holding rankings. ${ }^{5}$ This motivation measure can also be taken as the intensity of institution monitoring, given that the monitoring attention of institutional investors is limited.

To test the relation between IO and firm inefficient investment, we must address the potential endogeneity concern. Firms with higher or lower IO may differ in terms of

${ }^{2}$ Motivated monitoring institutional ownership is the ownership of institutional investors with high motivation to monitor the firm. Masulis and Mobbs (2014) also find that directors who have multiple directorships are motivated to monitor firms in which their directorships are relatively more prestigious.

${ }^{3}$ The opportunity costs of monitoring may not be ignored in the trade-off given the limited investors' attention.

${ }^{4}$ All our measures of inefficient investment are negatively associated with cumulative excess stock returns over the following year, suggesting that reducing investment inefficiency is beneficial to shareholders.

${ }^{5}$ In our robustness tests, we extend our study to all ten decile groups and find that institutional investors are motivated to monitor the firms in the top 3 decile groups.

This article is protected by copyright. All rights reserved. 
unobservable characteristics. Therefore, comparing the investment efficiency of firms with higher and lower IO may simply capture the effect of the unobservable differences rather than the effect of institutional investor monitoring. Furthermore, institutional investors may know firms in their portfolios well, and choose to invest more in firms with higher investment efficiency and better corporate governance. We mitigate the endogeneity due to the omitted variables and reverse causality using the instrumental variables (IV) based on the Russell index annual reconstitution. When firms switch between the Russell 1000 and 2000 indexes, are included in the Russell 2000 index for the first time, or leave the Russell 2000 index, there are exogenous changes in institutional holdings (e.g., Chang et al., 2015; Fich et al., 2015; Crane et al., 2016; Schmidt and Fahlenbrach, 2017). We estimate the relation between motivated monitoring IO and firm inefficient investment with a standard two-stage least squares (2SLS) estimation framework, in a manner similar to that of Fich et al. (2015) and Schmidt and Fahlenbrach (2017).

Our analyses yield three key findings. First, firms with greater motivated monitoring IO appear to make more efficient investment decisions: their new investment deviates less from predicted levels. Both under- and over-investment are negatively related to motivated monitoring IO, suggesting that firms with more institutional investor monitoring attention tend to invest more efficiently. The monitoring role of motivated institutions is economically important. A one standard deviation increase in motivated monitoring IO leads to a $\$ 22.8$ million reduction in annual under-investment and a $\$ 60.1$ million reduction in annual over-investment for the average sample-size firm with $\$ 2,648.1$ million in total assets. ${ }^{6}$ Second, the effect of the least motivated monitoring IO on firm under-investment is positive and statistically significant, whilst the effect on firm over-investment is statistically insignificant. This result supports our view that the effectiveness of institutional monitoring is influenced by the relative importance of the monitored firms within the institutional portfolios. Institutional investors do not have the same motivation to monitor all holding firms. We further show that the motivation of institutional investors to monitor a firm's investment increases monotonically with the weighting of the firm's market value in their portfolios. Third, we reveal the channels through which motivated monitoring by institutional investors improves investment efficiency. Motivated monitoring by institutional investors mitigates the over-investment problem in firms with more cash reserves or free cash flows and mitigates the under-

\footnotetext{
${ }^{6}$ The marginal effect numbers reported here are based on the inefficient investment estimated by the historical panel regressions.
}

This article is protected by copyright. All rights reserved. 
investment problem by reducing the career concerns of firm managers.

Our paper contributes to the literature in four ways. First, we contribute to a growing body of research that studies the relation between the monitoring attention of institutional investors and corporate decision making. Liu et al. (2016) and Kempf et al. (2017) find that the monitoring attention of institutional investors to one firm can be distracted by large shocks to the other firms in their portfolios. Fich et al. (2015) study motivated monitoring by institutional investors in the context of M\&As and find that M\&A targets with greater motivated monitoring IO receive better bidding prices. Consistent with these studies, our results support the limited attention hypothesis that institutional investors do not evenly distribute their monitoring attention amongst all firms in their portfolios. Our paper is directly related to Fich et al. (2015). However, since M\&A targets usually have a relatively small firm size and they are not the firms that actually make investment decisions, the benefits of motivated monitoring by institutional investors documented by Fich et al. (2015) may not be readily generalizable to the investment efficiency of an average firm in the market. By examining firm general investment inefficiency in a large panel sample, we further document that institutional investors' monitoring attention to a firm monotonically decreases when the relative importance of the firm's stock decreases in their portfolios. Based on this finding, we construct a general monitoring motivation weighted IO measure. We show that firms with greater monitoring motivation weighted IO make more efficient investments.

Second, our paper adds to the studies examining the factors that affect corporate investment, such as free cash flow (Jensen, 1986; Richardson, 2006), earnings management (McNichols and Stubben, 2008), the quality of financial reporting (Biddle et al., 2009; Cheng et al., 2013; Balakrishnan et al., 2014), management forecast ability (Goodman et al., 2013), product market competition (Gu, 2016; Stoughton et al., 2017), policy uncertainty (Gulen and Ion, 2016), accounting conservatism (Lara et al., 2016), mutual fund flow (Lou and Wang, 2016), and changes in generally accepted accounting principles (Shroff, 2017). Our paper identifies motivated monitoring IO as a new factor that can mitigate both firm over- and under-investment.

Third, our results shed light on the debate regarding which institutions are more likely to monitor corporate activities. Previous studies have found that institutional investors are heterogeneous and only a subset plays an active role in corporate governance (e.g., Brickley et al., 1988; Bushee, 1998; Chen et al., 2007; Cronqvist and Fahlenbrach, 2009; Fich et al., 2015). Recently, Schmidt and Fahlenbrach (2017) find that exogenous increases in passive IO weaken firm corporate governance and reduce subsequent firm

This article is protected by copyright. All rights reserved. 
performance, while Appel et al. (2016b) document that passive mutual funds influence firms' governance choices by means of their large voting blocs and improve firms' longterm performance. In our paper, we find that motivated monitoring by all types of institutional investors, regardless of whether investors are active or passive, mitigates firm inefficient investment, supporting the view that passive institutional investors pay attention to important firms in their portfolios.

Finally, our paper complements two working papers on institutional investors and corporate investment. Mullins (2014) finds that firms' index fund ownership rises after they are newly included in the Russell 1000 index. The increase of index fund ownership in such firms leads to lower capital expenditures and less diversifying acquisition activities. On the contrary, Wong and Yi (2015) find that institutional investors induce Russell 2000 firms to invest more and increase their investment sensitivity to changes in investment opportunities. Our paper differs from these two studies in the following aspects. First, we emphasize the incentive of institutions in monitoring corporate investment decisions, while these two studies examine either index fund ownership or total IO. Second, we investigate firm investment inefficiency and examine both over- and under-investment in our analyses, whereas Mullins (2014) and Wong and Yi (2015) study the level of investment. Third, we find that the negative relation between motivated monitoring IO and firm inefficient investment remains robust for different types of institutional investors. The rest of the paper is organized as follows. Section 2 develops our hypotheses. Section 3 describes data sources and variable definitions. Section 4 presents our main test results and addresses endogeneity. Section 5 discusses how motivated monitoring by institutional investors can reduce inefficient investment and provides robustness test results. Finally, Section 6 concludes.

\section{Hypotheses and empirical predictions}

In a perfect, frictionless capital market (Modigliani and Miller, 1958), firms make their financing and investment decisions independently. The neoclassical theory of investment predicts that a firm's growth opportunity, commonly measured by Tobin's Q, is the only determinant of its investment policy (Hayashi, 1982; Abel, 1983). Given this ideal framework, the optimal level of investment is achieved when the new investment's marginal benefit is equal to the sum of its marginal cost and the adjustment cost of capital. However, actual firm investment usually deviates from the optimal level due to frictions in the capital market such as managerial optimism or pessimism, information asymmetry,

This article is protected by copyright. All rights reserved. 
conflict of interests between managers and shareholders, and external financing costs (e.g., Malmendier and Tate, 2005; Biddle et al., 2009; Aghion et al., 2013; Asker et al., 2015).

Previous studies have suggested that greater inefficient investment is associated with lower subsequent firm performance (e.g., Titman et al., 2004; Cai and Zhang, 2011). Therefore, firm shareholders have a strong incentive to monitor managers' investment decisions. Institutional investors are usually more active and effective than individual investors in these monitoring activities, as shareholder activism is costly and it is difficult for individual investors to intervene collectively. Indeed, the attention of institutional investors is limited, and they may not allocate their monitoring attention equally to all the stocks in their portfolios (Kempf et al., 2017). The motivation for institutions to engage in monitoring is positively related to the benefits of monitoring and negatively related to the cost of monitoring. Fich et al. (2015) find that the institutional investors in M\&A targets have a greater incentive to monitor deal transactions when the target stocks are more important relative to the other stocks in their portfolios. Following Fich et al. (2015), we conjecture that institutional investors have the most (least) motivation to monitor firms whose holding value weights rank among the top (bottom) 10\% of the stocks in the investors' portfolios. Intuitively, the rank of a stock's weight in an institutional investor's portfolio is positively related to the benefit of monitoring. Given limited attention, even if the actual costs of monitoring are equal for all firms in the portfolio, the opportunity cost of monitoring is highest for firms in the bottom $10 \%$ of the portfolio. When institutional investors monitor the firms in the bottom $10 \%$ of their portfolios, the relatively more important firms may receive less effective monitoring. The above discussion leads to our first hypothesis:

- H1: Motivated monitoring by institutional investors is positively associated with investment efficiency.

Our next two hypotheses examine the direction of firm inefficient investment. Previous studies have documented two agency problems leading to firm under-investment. First, it takes managers' time and effort to look for positive net present value (NPV) projects. Managers may instead enjoy "the quiet life" if there is a lack of corporate governance (Hart, 1983; Bertrand and Mullainathan, 2003). Institutional investor monitoring may inhibit this kind of managerial slack. Second, the outcomes of new projects remain uncertain, even if managers spend a great amount of effort supervising the projects. When information is asymmetrical, the ex ante quality of new projects and managerial

This article is protected by copyright. All rights reserved. 
effort are not observable. Many managers' employment and compensation contracts are based on the noisy ex post profitability of projects, instead of the ex ante mean of the projects' returns and actual managerial effort. Managers may choose not to invest in positive NPV projects because the possibility of loss could damage their reputation and job security. Institutional investors may possess greater professional awareness of the volatility of profitability than do other investors. Aghion et al. (2013) find that institutional investors may reduce managers' career concerns and increase firm innovation activities. In addition to these two agency-problem-based explanations, firms may not capture positive NPV investment opportunities due to the debt overhang problem (Hennessy, 2004). Institutional investors may mitigate the debt overhang problem by reducing a firm's debt borrowing cost. This discussion leads to our second hypothesis:

- H2: Motivated monitoring by institutional investors mitigates firm under-investment.

Managers may use excessive firm cash holdings to pursue benefits for themselves. Jensen (1986) predicts that the managerial empire building tendency leads to firm over-investment. The prediction is supported by the empirical findings of Blanchard et al. (1994) that firms over-invest cash windfalls. Harford (1999) finds that firms with higher cash holdings tend to make acquisitions with poor subsequent operational performance, while Richardson (2006) finds that firms with positive free cash flow tend to over-invest. Titman et al. (2004) document a negative relation between over-investment and stock returns, indicating that over-investment by managers is not in the interest of shareholders. We expect that a firm with greater motivated monitoring IO will exhibit less over-investment. Formally stated, our third hypothesis is as follows:

- H3: Motivated monitoring by institutional investors mitigates firm over-investment.

\section{Data and variable descriptions}

\subsection{Data sources}

Our sample covers U.S. firms with available stock return data in the Centre for Research in Security Prices (CRSP) and accounting information in the Compustat Fundamentals Annual files. Firms in the financial (SIC 6000-6999) and regulated utility (SIC 4900-4999) industries are excluded from our sample. Data on institutional holdings are obtained from the Thomson Financial CDA/Spectrum Institutional (13F) database. In

This article is protected by copyright. All rights reserved. 
order to prevent the reuse of institutional investor identifiers and institution type misclassification in the $13 \mathrm{~F}$ database, we apply Brian Bushee's institution type correction to our institutional holding data. Our sample period is from 1995 to $2015,^{7}$ a period for which Russell index constituent data are available for use on Bloomberg. Once these screening criteria have been applied, our baseline sample contains 11,903 unique firms with 92,546 firm-year observations. In addition, we collect the corporate governance measure, the G-index scores (Gompers et al., 2003), from Institutional Shareholder Services (ISS, formerly RiskMetrics).

\subsection{Definition of institutions with motivation to monitor}

The existing institutional investor literature has documented the growth of general institutional investors in the U.S. stock market over the past four decades. ${ }^{8}$ Panel A of Table A1 shows that both the U.S. stock market value and the total market value of institutional holdings grew approximately four times over during the sample period. Institutional holdings accounted for about $50 \%$ of the total stock market value in September 1995; 65.5\%, the highest level, in September 2009; and 59.6\% in September 2015 thus the time-series trend of institutional ownership is not a major concern in this study. The annual average number of stocks in an institutional investor's portfolio is over 200, suggesting that a typical institutional investor is unlikely to allocate its monitoring attention evenly to every firm.

We use stock holding value ranking in an investor's portfolio to differentiate its monitoring motivation among all the stocks in the portfolio. All stocks in an investor's portfolio are sorted into ten decile groups by each stock's holding value. As shown in Panel B of Table A1, institutional investors distribute their holding value unevenly across these ten decile groups. On average, more than $40 \%$ of their portfolio value is concentrated in the decile 1 group, which comprises the largest $10 \%$ of the holding positions in their portfolios. In addition, the average holding value per stock position (\$105.4 million) in the decile 1 group is almost five times greater than that in the decile 2 group $(\$ 23.7$ million). In comparison, only $0.7 \%$ of institutional investors' portfolio value is represented by the decile 10 group, which comprises the smallest $10 \%$ of the holding positions in their portfolios. It is obvious that the performance of the firms in the decile 1 group is

${ }^{7}$ According to Thomson Reuters, there are some issues with IO data after 2010. Our main results are robust if we restrict our sample period from 1995 to 2010.

${ }^{8}$ Institutional holdings accounted for about $50 \%$ of the total stock market value in September 1995, the highest level $65.5 \%$ in September 2009, and 59.6\% in September 2015. The time-series trend of IO is not a major concern in our study.

This article is protected by copyright. All rights reserved. 
much more important to institutional investors than is the performance of the rest of the holding firms in their portfolios. Therefore, we expect that the benefits of monitoring and the motivation to monitor the firms in the decile 1 group should be the highest of all the decile groups.

Following Fich et al. (2015), we define institutional investors with the motivation to monitor a firm as the investors whose decile 1 groups include the firm's stock. We aggregate the ownership of all investors with the motivation to monitor at the firm level and denote the sum as the total motivated monitoring IO: Tmi $1_{i, t}$. Similarly, the firms in the decile 10 group are those that institutional investors have the least incentive to monitor. For comparison purposes, we also aggregate the ownership of these institutional investors at the firm level and construct the variable $\operatorname{Tmi}_{i, t}$, the ownership of investors who have the least motivation to monitor firm $i$. Panel $\mathrm{C}$ of Table A1 shows that, on average, the ownership of investors with the most motivation to monitor is approximately $9 \%$ of firm shares while the ownership of investors with the least motivation to monitor is only $1 \%$ of firm shares. We also calculate two alternative measures of motivated monitoring IO: $N m i 1_{i, t}$ the number of institutional investors with the most motivation to monitor and $P m i 1_{i, t}$ the ratio of $N m i 1_{i, t}$ to the number of total institutional investors in firm $i$.

\subsection{Investment inefficiency measures}

We identify inefficient investments as the deviation from the level that would be predicted by a firm-specific model of investment. Motivated by Richardson (2006) and Stoughton et al. (2017), we estimate the following regression and use the regression residuals as our proxies for firm-specific inefficient investment:

$$
\begin{aligned}
\text { INew }_{i, t}= & \alpha+\beta_{1} \frac{V}{P}_{i, t-1}+\beta_{2} \text { Leverage }_{i, t-1}+\beta_{3} \text { Cash }_{i, t-1}+\beta_{4} \text { Age }_{i, t-1}+\beta_{5} \text { Size }_{i, t-1} \\
& +\beta_{6} \text { Return }_{i, t-1}+\beta_{7} I N e w_{i, t-1}+\delta_{i}+\mu_{t}+\epsilon_{i, t}
\end{aligned}
$$

where $I N e w_{i, t}$ is the new investment level for firm $i$ in year $t$ and $I N e w_{i, t}=I T o t a l_{i, t}-$ IMaintenance $_{i, t}$. ITotal ${ }_{i, t}$ is the overall investment, and IMaintenance $_{i, t}$ is the investment expenditure to maintain assets in place. The previous finance and economics literature has shown that firm investment is jointly determined by growth opportunities, financial constraints, and other firm characteristics. ${ }^{9}$ Firm growth opportunities are

${ }^{9}$ See Hubbard (1998) for a detailed literature review.

This article is protected by copyright. All rights reserved. 
measured by $V / P$, where $V$ represents the assets in place and $P$ is the market value of the firm (Ohlson, 1995; Feltham and Ohlson, 1996). ${ }^{10}$ Because $P$ is the sum of $V$ and the value of future growth, $V / P$ is negatively related to a firm's growth opportunities. We expect a negative relation between $V / P$ and $I N e w$. The financial constraints are measured by Leverage and Cash. Because a lower leverage ratio and higher cash holdings indicate lower financial constraints, INew is expected to be negatively related to Leverage and positively related to Cash. We control for the following firm characteristics in Equation (1): firm age (Age), the natural log of firm total assets (Size), cumulative stock returns over the previous year (Return), and the lag of new investment $\left(I N e w_{t-1}\right)$. We also include the firm fixed effects $\left(\delta_{i}\right)$ to control for unobserved firm characteristics and the year fixed effects $\left(\mu_{t}\right)$ to control for the factors such as stock market level trends and business cycles. $\epsilon_{i, t}$ are clustered by firm. ${ }^{11}$ Following Richardson (2006), all variables are winsorized at the top and bottom 1\%. Please refer to Appendix A for the detailed definitions and construction of these variables.

We measure firm inefficient investment in our empirical analyses as Ine $_{i, t}=\mid I N e w_{i, t}$ $-\widehat{I N e w}_{i, t} \mid$. As discussed in the previous sections, both under- and over-investment are detrimental to the interests of shareholders. However, the underlying mechanisms of these two cases could be different. We further define the under-investment proxy vari-

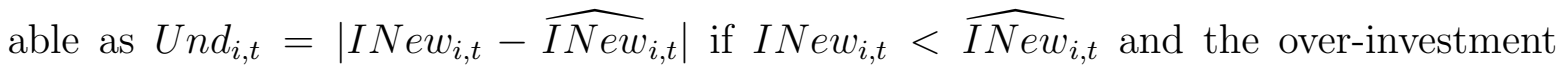

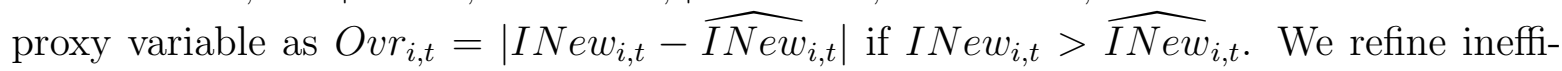
cient investment as regards its direction in order to distinguish the roles of motivated monitoring by institutional investors in mitigating two different sources of investment inefficiency.

To avoid the "look ahead bias" concern due to the use of unknown information at the time of our model prediction, we estimate Equation (1) for each year $t$ of the period 1995-2015 using the historical panel data from 1981 to year $t$. We trace the sample back to 1981 in order to increase the power of our optimal investment prediction. For example, we run a panel regression from 1981 to 1995 to estimate $\widehat{I N e w}_{i, 1995}$, a panel regression from 1981 to 1996 to estimate $\widehat{I N e w}_{i, 1996}$, and so on. The predicted investment $\widehat{I N e w}_{i, t}$ is the result of twenty-one historical panel regressions, for each year $t$ from 1995 to 2015. We denote the inefficient investment proxy variables estimated by this procedure as Inef $1_{i, t}, U n d 1_{i, t}$, and $O v r 1_{i, t} \cdot{ }^{12}$ Alternatively, we follow Richardson (2006) and

${ }^{10}$ Richardson (2006) provides the detailed definition of $V / P$.

${ }^{11}$ Petersen (2009) suggests that when the number of firms is much larger than the number of years, clustering standard errors by firm is similar to double clustering standard errors by firm and year.

${ }^{12}$ We also estimate Equation (1) with five-year historical rolling windows between year $t-4$ and year

This article is protected by copyright. All rights reserved. 
Stoughton et al. (2017) to estimate Equation (1) by a single panel regression from 1995 to 2015. The inefficient investment proxy variables are defined as Ine $f 2_{i, t}, U n d 2_{i, t}$, and $\operatorname{Ovr} 2_{i, t}$.

Table A2 reports the corresponding regression results for the two specifications of Equation (1). The left panel displays the average coefficients estimated by the twenty-one historical panel regressions. The numbers of negative $(-)$ and positive $(+)$ significant coefficients at the $1 \%$ level are reported in parentheses. The right panel presents the coefficients estimated by the single panel regression between 1995 and 2015. The negative coefficients of $V / P$ suggest that firms with good growth opportunities increase their investment. The negative coefficients of Leverage and the positive coefficients of Cash indicate that firms with lower financial constraints increase their investment. The negative coefficients of Size and Age are consistent with the findings in Stoughton et al. (2017) and the firm life cycle hypothesis. The positive coefficients of Return and INewt-1 are consistent with Richardson (2006) and Stoughton et al. (2017). The average $R^{2}$ of the historical panel regressions is 0.208 and the $R^{2}$ of the single panel regression is 0.259 , suggesting that both our investment model specifications can explain a significant portion of the variations in firm-specific investment.

\subsection{Descriptive statistics}

Panel C of Table A1 presents the descriptive statistics of all the variables in our empirical analyses. The mean and standard deviation of INew are 0.10 and 0.15 , respectively, which are comparable to those (0.08 and 0.13) reported in Richardson (2006). The mean and standard deviation of the difference between INew and $\widehat{I N e w}$ estimated by the single panel regression are 0.00 and 0.13 , respectively, which are similar to those $(0.00$ and 0.11) reported in Richardson (2006). The summary statistics of all our investment related variables are also comparable to those of Stoughton et al. (2017). The means of our motivated monitoring by institutional investor proxies are 0.09 (Tmi1), 9.3 (Nmi1), and 0.03 (Pmi1), which are comparable to those (0.07, 9.0, and 0.02, respectively) reported in Fich et al. (2015). Our proxies are slightly larger because Fich et al. (2015) focus on the institutional investors of M\&A targets and their sample is from 1984 to 2011.

$t$. Our untabulated results are qualitatively similar to those reported in this paper.

This article is protected by copyright. All rights reserved. 


\section{Main results}

In this section, we present the empirical test results for the effectiveness of motivated monitoring by institutional investors. We first investigate the role of motivated monitoring by institutional investors in firm investment decisions with both ordinary least squares (OLS) and 2SLS regressions. We then study if the monitoring motivation varies across different types of institutional investors.

\subsection{Motivated monitoring institutional ownership and ineffi- cient investment: Baseline OLS regressions}

In untabulated tests, we find that inefficient investment is negatively associated with firm subsequent stock performance. ${ }^{13}$ Therefore, we expect that institutional investors with motivation to monitor are incentivized to monitor firm investment activities and increase firm investment efficiency. To test our three hypotheses, we adapt the following baseline model to capture the effects of institutional investors on investment:

$$
\begin{aligned}
\text { Inefficient investment }_{i, t+1}= & \alpha+\beta_{1} \text { Tmi }_{i, t}+\beta_{2} * \text { Tmi }_{10} 0_{i, t}+B * \text { Control variables }_{i, t} \\
& +\theta_{j}+\mu_{t}+\epsilon_{i, t}
\end{aligned}
$$

where Inefficient investment ${ }_{i, t+1}$ is one of the following six proxies: Ine f 1 , Und1, Ovr 1 , Inef2, Und2, and Ovr2. Tmi1 is the total ownership of institutional investors with the most motivation to monitor. To help us differentiate the monitoring roles of investors with the most motivation to monitor from those with the least motivation to monitor, we add Tmi10 in Equation (2), either individually or jointly, along with Tmi1. We follow Stoughton et al. (2017) and control for MTB, Leverage, Cash, Size, ${ }^{14}$ Tangibility, and Age. To control for industry-specific and time-specific investment variations, we include the Fama-French 48 industry $\left(\theta_{j}\right)$ and year $\left(\mu_{t}\right)$ fixed effects in Equation $(2)$. The standard errors are clustered by firm.

Table A3 presents the results of estimating Equation (2). Panel A is based on the inefficient variables estimated by the historical panel regressions and Panel B is based on those estimated by the single panel regression. All the coefficients of Tmi1 are negative and

\footnotetext{
${ }^{13}$ Results are available upon request.

${ }^{14}$ To mitigate the concern that our monitoring motivation measure may simply pick up a size effect, we control for firm size in both Equation (1) and (2).
}

This article is protected by copyright. All rights reserved. 
statistically significant, suggesting that motivated monitoring by institutional investors improves firm investment efficiency. Both under- and over-investment are mitigated by institutional investors with motivation to monitor. These results are consistent with our three hypotheses. On the other hand, we find that Tmi10 has a significantly positive effect on Inef in both Panel A and Panel B, indicating that firms with greater Tmi10 (least motivated monitoring IO) make a more inefficient investment. This positive relation is only statistically significant in the under-investment subsample, which may be explained by either the "quiet life" hypothesis or managers' career concerns. We directly test these two explanations in Section 5.

\subsection{Motivated monitoring by institutional investors and ineffi- cient investment: 2SLS regressions}

Our baseline regression results may be driven by the endogeneity between motivated monitoring by institutional investors and inefficient investment. The first concern is the potential omitted variable bias. Although we have controlled for several firm characteristics in Equation (2), there may be some unobserved firm characteristics correlated with both motivated monitoring IO and inefficient investment. The second concern involves the reverse causality that institutional investors with motivation to monitor may have private information on firms' investment efficiency, and may choose to invest more in firms with higher investment efficiency (Giannetti and Simonov, 2006). Inspired by recent studies on firms switching between the Russell 1000 and 2000 indexes, we adopt an IV approach similar to Fich et al. (2015), Crane et al. (2016), and Schmidt and Fahlenbrach (2017).

The Russell 1000 and 2000 indexes are reconstituted in June each year. Based on the market capitalization of the common stocks of U.S. firm at May 31, the largest 1,000 firms are included in the Russell 1000 index and the subsequent 2,000 firms are included in the Russell 2000 index. ${ }^{15}$ In 2005, about $\$ 90$ billion worth of institutional assets tracked the Russell 1000 index and about $\$ 200$ billion worth of institutional assets tracked the Russell 2000 index (Chang et al., 2015). Both indexes are value-weighted and no other criteria besides market capitalization is used in the index reconstitution. Therefore, when a stock drops from the Russell 1000 to the Russell 2000 index or is added in the Russell 2000 index for the first time, the index tracking IO of the stock will

\footnotetext{
${ }^{15}$ The London Stock Exchange (LSE) bought Russell Investments in 2014. The merged firm is called FTSE Russell. For the detailed explanations of the Russell Index reconstitution, please refer to www.ftserussell.com/research-insights/russell-reconstitution.
}

This article is protected by copyright. All rights reserved. 
increase exogenously. In a similar manner, there is a negative and exogenous shock on a firm's index tracking IO when a stock moves up from the Russell 2000 to the Russell 1000 index or is excluded from the Russell 2000 index. When index tracking institutions adjust the stock weights in their portfolio, there will also be an exogenous shock on the stock weights in the other institutions' portfolios. This is because the Russell index reconstitution may affect stock returns (Chang et al., 2015) and institutional investors usually trade with each other. For the firms that are not affected by the Russell index reconstitution, there is still an exogenous shock on their weights in the institutional portfolios when institutional investors adjust the weights of the other affected stocks over the annual Russell index reconstitution periods.

The switch of firms between the two Russell indexes and the inclusion of firms in or their exclusion from the Russell 2000 index are used as the IVs in our first stage regression:

$$
\begin{aligned}
\operatorname{Tmi}_{i, t}= & \alpha+\beta_{1} R 1 T R 2_{i, t}+\beta_{2} R 2 T R 1_{i, t}+\beta_{3} R 2 T N_{i, t}+\beta_{4} N T R 2_{i, t} \\
& +B * \text { Control variables }{ }_{i, t}+\theta_{j}+\mu_{t}+\epsilon_{i, t}
\end{aligned}
$$

where $R 1 T R 2_{i, t}\left(R 2 T R 1_{i, t}\right)$ is an indicator variable equal to 1 if firm $i$ switches from the Russell 1000 (2000) index to the Russell 2000 (1000) index in year $t$ and 0 otherwise. $R 2 T N_{i, t}\left(N T R 2_{i, t}\right)$ is an indicator variable equal to 1 if firm $i$ leaves (enters) the Russell 2000 index and 0 otherwise. The relevancy condition of our IVs is satisfied because the index reconstitution affects the motivated monitoring IO in all firms. The exclusion restriction is also satisfied because stock returns are stochastic and the only index assignment rule is mechanically based on the rank of stock market capitalization. Firms switching between the two Russell indexes should not have any direct effect on their investment behavior. We control for MTB, Leverage, Cash, Size, Tangibility, and Age in Equation (3). $\theta_{j}$ and $\mu_{t}$ are the Fama-French 48 industry and year fixed effects, respectively. In the second stage regression, we estimate Equation (2) by replacing Tmi1 with $\widehat{T m i 1}$, the predicted value of motivated monitoring IO from Equation (3).

Panel A of Table A4 presents the 2SLS regression results. Column (1) reports the first stage regression results. $R 1 T R 2, R 2 T N$, and $N T R 2$ are negatively associated with Tmi1, while $R 1 T R 2$ is positively correlated with it. The signs of our IV coefficients are generally in line with those of Fich et al. (2015). The results of the second stage regressions are presented in Columns (2)-(7). In Columns (2) and (5), the dependent variables are proxies for firm inefficient investment: Ine 1 and Inef2. The coefficients of $\widehat{T m i 1}$ are negative and statistically significant at the $1 \%$ level, supporting our hypothesis H1

This article is protected by copyright. All rights reserved. 
that motivated monitoring by institutional investors improves firm investment efficiency. In Columns (3) and (6), the dependent variables are under-investment proxies: Und1 and $U n d 2$. The coefficients of $\widehat{T m i 1}$ remain negative and statistically significant at the $1 \%$ level. The marginal effect of $\widehat{T m i 1}$ on the under-investment proxies is economically significant. For example, a one standard deviation increase in $\widehat{T m i 1}$ is associated with a $0.86 \%$ decrease in $U n d 1$ for the average sample-size firm with $\$ 2,648.1$ million worth of total assets. This result confirms our hypothesis H2 that motivated monitoring by institutional investors mitigates firm under-investment. In Columns (4) and (7), the dependent variables are over-investment proxies: Ovr 1 and Ovr 2 . The negative and statistically significant coefficients of $\widehat{T m i 1}$ confirm that motivated monitoring by institutional investors mitigates firm over-investment. The economic significance is such that a one standard deviation increase in $\widehat{T m i 1}$ results in a $2.27 \%$ decrease in Ovr1, which translates into a $\$ 60.1$ million reduction in annual over-investment for the average sample-size firm. This result provides direct support for our hypothesis H3 that motivated monitoring by institutional investors can mitigate firm over-investment.

As an alternative test, we adopt the first difference specification used in Schmidt and Fahlenbrach (2017) to remove any firm-specific time-invariant unobservable firm characteristics. We replace all the dependent variables and control variables of firm characteristics in Panel A of Table A4 by their annual change terms. The first difference specification may further mitigate the causality concern that institutional investors choose to invest more in firms with higher investment efficiency. Panel B of Table A4 presents the results of our 2SLS regressions with the first difference specification. We find that the increase in motivated monitoring IO may reduce the subsequent firms' investment inefficiency.

\subsection{Monitoring motivation and institution types}

Institutional investors differ in terms of investment strategies, fiduciary duties, and trading horizons. Previous studies have documented that long-term and independent investors are more active in monitoring firms than are short-term and grey investors (Chen et al., 2007). However, Appel et al. (2016b) find that by removing firms' takeover defenses and increasing firms' equal voting rights, passive mutual funds may improve firm governance and long-term performance. Institutional investors with motivation to monitor include all types of investors covered in the $13 \mathrm{~F}$ universe. Therefore, a natural question is whether the monitoring motivation of institutional investors varies across different institution types.

This article is protected by copyright. All rights reserved. 
First, we divide institutional investors into independent (Tmi_Ind) and grey investors (Tmi_Grey), based on the business relationship between institutional investors and the firms in which they hold stocks (e.g., Brickley et al., 1988; Almazan et al., 2005; Chen et al., 2007). Independent investment advisors, investment companies, and public pension funds are classified as independent investors. Private pension funds, banks, and insurance companies are classified as grey investors because their monitoring ability may be compromised due to business interests. ${ }^{16}$ Second, we separate institutional investors into transient (Tmi_Tran) and non-transient investors (Tmi1_NonTran) based on their investment horizons. Bushee (1998) classifies institutional investors as dedicated, quasi-index, and transient investors based on their investment patterns such as those of portfolio turnover, diversification, and momentum, etc. Following Chen et al. (2007), we take transient investors as short-term investors, while dedicated and quasiindex investors as non-transient or long-term investors.

Panel A of Table A5 presents the 2SLS regression results of inefficient investment on Tmi_Ind and Tmi_Grey and Panel B of Table A5 presents similar regression results for those variables in first difference terms. Similarly, Panel C of Table A5 presents the 2SLS regression results of inefficient investment on Tmi_Tran and Tmi_NonTran and Panel D of Table A5 presents the regression results for those variables in first difference terms. Among all specifications, the motivated monitoring IO proxies are negatively related to investment inefficiency. These results suggest that the monitoring incentives derived from the relative importance of firms in institutional investors' portfolios are independent of investor characteristics. As conjectured by Chen et al. (2007), grey and transient institutions are less likely to engage in monitoring activities. However, we find that even for the institutions usually taken as inefficient monitors, the benefits of monitoring still increase with the holding firms' relative value in their portfolios. ${ }^{17}$ Therefore, all institutional investors with motivation to monitor improve firm investment efficiency, regardless of their types.

${ }^{16}$ We follow Brian Bushee's institution type classification for institutional investors after 1998.

${ }^{17}$ In terms of economic effect, independent and non-transient investors still have a stronger impact on investment inefficiency than do grey and transient investors. The means of Tmi_Ind (0.07) and Tmi_NonTran (0.06) are greater than those of Tmi_Grey (0.02) and Tmi_Tran (0.02), as reported in Panel C of Table A1.

This article is protected by copyright. All rights reserved. 


\subsection{Alternative measures of motivated monitoring by institu- tional investors}

In our main analyses, we use the ownership of institutional investors with motivation to monitor as our proxy for investor monitoring attention. To address the concern that the distribution of $T$ miN is highly skewed, ${ }^{18}$ we examine the two alternative measures of motivated monitoring IO that have been used in Fich et al. (2015): (1) the proportion of institutional investors with motivation to monitor among a firm's institutional investors (Pmi1), and (2) the natural log of one plus the number of institutional investors with motivation to monitor $(\operatorname{Ln}(1+N m i 1))$. We rerun our 2SLS regression analyses, i.e., Equation (2) and (3). We substitute Pmi1 and $L n(1+N m i 1)$ as the dependent variables in the first stage regressions and use their predicted values as independent variables in the second stage regressions. The results are tabulated in Panel A and Panel B of Table A6. We find that the negative relation between motivated monitoring IO and inefficient investment remains robust with these two alternative measures.

Based on a cost-benefit trade-off, institutional investors should consider not only the ranking of stocks in their portfolios, but also the absolute size of their positions in each stock. Institutional investors are motivated to monitor firms that form a significant percentage of their portfolio, where the reward of monitoring will be the greatest. However, monitoring costs are lower when institutional investors possess greater voting rights. Hence, institutional investors are most likely to monitor firms when they both possess significant control over the firm and have a considerable portfolio allocation to the firm. Next, we construct a general measure of monitoring attention-weighted institutional ownership that covers both an investor's monitoring attention to a firm and its control over the firm:

$$
T M A_{i}=\ln \left(1+\sum_{j=1}^{N} \omega_{i, j} * I O_{i, j} * 10000\right)
$$

where $T M A_{i}$ is the total institutional investor monitoring attention to firm $i, N$ is the total number of institutions investing in firm $i, \omega_{i, j}$ is the market value weighting of firm $i$ 's stock in institution $j$ 's portfolio, and $I O_{i, j}$ is the ownership by institution $j$ in firm $i$. In our aggregate measure, $\omega_{i, j}$ represents institution $j$ 's motivation to monitor firm $i$ and $I O_{i, j}$ represents institution $j$ 's monitoring power over firm $i$. Intuitively, $T M A$ is a weighted average of a firm's IO, with the weights being the institutional investors'

${ }^{18}$ The mean of Tmi1 is 0.09 and the mean of Tmi10 is 0.01 .

This article is protected by copyright. All rights reserved. 
monitoring motivation. Panel $\mathrm{C}$ of Table A1 reports the summary statistics for TMA. We predict that a firm with a greater $T M A$ has higher aggregated institutional investor monitoring attention. Consistent with our prediction, Panel $\mathrm{C}$ of Table A6 shows that the coefficients of IVTMA are all negative and statistically significant in the second stage regressions. ${ }^{19}$

\section{$5 \quad$ Further discussions and robustness tests}

Our results so far have documented a significantly negative relation between motivated monitoring IO and firm inefficient investment. Next, we attempt to investigate the channels through which institutional investors with motivation to monitor mitigate firm over- and under-investment. We conclude this section with a battery of robustness tests.

\subsection{Motivated monitoring, cash, and over-investment}

Empire building activities may increase the resources under the control of a firm's managers (Jensen, 1986). From an agency perspective, managers have an incentive to overinvest and grow their firms beyond the optimal size. Previous studies have documented that the empire building problem is more severe for firms with larger amounts of free cash flow (e.g., Stulz, 1990; Lang et al., 1991; Brush et al., 2000; Richardson, 2006). Motivated monitoring by institutional investors should therefore have a more important role of curbing managers' over-investment tendencies when firms have more cash reserves or free cash flows. We test this hypothesis with the following model specification:

$$
\begin{aligned}
\text { Ovr }_{i, t+1}= & \alpha+\beta_{1} \widehat{\text { Tmi1 }}_{i, t}+\beta_{2} \widehat{\text { Tmi1 }}_{i, t} * \text { Cash measures }_{i, t}+\beta_{3} \text { Cash measures }_{i, t} \\
& +B * \text { Control variables }_{i, t}+\theta_{j}+\mu_{t}+\epsilon_{i, t}
\end{aligned}
$$

where $\widehat{\operatorname{Tmi}}_{i, t}$ is the predicted value of $T m i 1_{i, t}$ in Equation (3), Cash measures are either the cash reserve ratio ( Cash) or the free cash flow $(F C F)$, and Control variables are the same as those used in Equation (2). We adopt Richardson's (2006) FCF definition: ${ }^{20}$

$$
F C F_{i, t}=\text { Operating cash } \text { flow }_{i, t}-\text { IMaintaince }_{i, t}+R \& D_{i, t}-\widehat{I N e w}_{i, t}
$$

\footnotetext{
${ }^{19}$ Our findings are robust in OLS regressions.
}

${ }^{20}$ Because two different specifications are used to estimate the predicted new investment $\widehat{I N e w}$, we accordingly have two measures of free cash flows. $\widehat{I N e w}$ is estimated by the historical panel regressions in $F C F 1$ and the single panel regression in $F C F 2$.

This article is protected by copyright. All rights reserved. 
Empire building is usually observed in firms with positive free cash flows (Richardson, 2006). When estimating Equation (5), we follow Dittmar and Mahrt-Smith (2007) and exclude the firm-year observations with negative FCF. The regression results of Equation (5), presented in Table A7, show that firms with more cash holdings and free cash flows are more likely to over-invest. This finding is consistent with the prediction that managers may engage in empire building and over-invest firms' abundant cash. More importantly, the coefficients $\left(\beta_{2}\right)$ of the interaction terms are all negative and statistically significant, indicating that the role of institutional investors with motivation to monitor in firm over-investment is more important for firms with a higher empire building tendency.

\section{2 "Quiet life" or "career concern"}

Firms may under-invest if managers do not exert enough effort to seek investment opportunities. There are two possible explanations that predict firm under-investment given a lack of investor monitoring. On the one hand, managers may prefer a "quiet life" (e.g., Hart, 1983; Bertrand and Mullainathan, 2003), because it is costly for them to seek positive NPV projects and make difficult investment decisions. We refer to the first explanation as the "quiet life" hypothesis. On the other hand, managers are risk averse and may choose not to invest in risky projects. Rather than being lazy, managers may have job security concerns if their new projects have unfavorable outcomes due to random factors (Aghion et al., 2013). We designate the second potential explanation as the "career concern" hypothesis.

Although motivated monitoring by institutional investors may mitigate firm underinvestment, the predicted joint effect of shareholder monitoring and other external monitoring on firm under-investment differs according to the "quiet life" and "career concern" hypotheses. If the "quiet life" hypothesis is correct, monitoring by investors has a less important role when market competition is higher. This is because market competition is positively related to the probability of firm bankruptcy (Hart, 1983). Firm managers are less likely to enjoy "quiet lives" in a competitive market. However, the "career concern" hypothesis predicts the opposite. In a highly competitive market, the probabilities of failures of new projects are higher, which would thus increase the career concerns of firm managers and lead to under-investment. Institutional investors may alleviate the managers' career concerns as these investors are informed and can effectively distinguish random negative outcomes from a lack of managerial ability (Aghion et al., 2013). Therefore, if the "career concern" hypothesis is correct, monitoring by institutional investors

This article is protected by copyright. All rights reserved. 
has a more important role in mitigating under-investment when market competition is greater.

These two hypotheses also have opposite predictions when managerial entrenchment is high. If the "quiet life" hypothesis is correct, managers with a lower risk of being fired have less incentive to seek investment opportunities. Therefore, monitoring by investors has a stronger effect on mitigating firm under-investment when managers are more entrenched. However, managers have more job security when managerial entrenchment is higher. If the "career concern" hypothesis is correct, managers are less likely to underinvest when their jobs are more entrenched. Therefore, monitoring by investors has a weaker effect in mitigating firm under-investment in this case. We use the following model specification to test these two possible hypotheses:

$$
\begin{aligned}
\text { Und }_{i, t+1}= & \alpha+\beta_{1} \widehat{\text { Tmi }}_{i, t}+\beta_{2} \widehat{\text { Tmi }}_{i, t} * \text { Competition or Entrenchment }_{i, t}+\beta_{3} \\
& \text { Competition or Entrenchment } \\
i, t & +B * \text { Control variables } i, t \\
+ & \theta_{j}+\mu_{t}+\epsilon_{i, t}
\end{aligned}
$$

where Competition is 1 - Lerner ratio (Aghion et al., 2013) and Entrenchment is Gompers et al.'s (2003) G-index. The Lerner ratio is the median growth margin of the industry to which firms are assigned. ${ }^{21}$ As the $G$-index is only available for the S\&P 1500 companies from 1995 to 2007, our sample size for the entrenchment analysis is smaller than it is for the main tests.

Table A8 presents the results. Consistent with the "career concern" hypothesis, when market competition is greater and managers are less entrenched, the under-investment problem is more severe. Furthermore, when career concerns are greater, the effect of motivated monitoring by institutional investors on under-investment is more prominent. These results support the "career concern" hypothesis but oppose the "quiet life" hypothesis.

\subsection{Institutional ownership by decile monitoring motivation}

In Table A3, we show that Tmi1 and Tmi10 have opposite effects on firm investment inefficiency. To further support our view that the motivation of institutional monitoring is positively associated with the relative importance of firm stocks in institutional portfolios, we sort all stocks into decile groups by their holding value in institutional

${ }^{21}$ Following Aghion et al. (2013), the Lerner ratio is based on 3-digit SIC codes and the industry fixed effects are based on 4-digit SIC codes in the regressions related to market competition.

This article is protected by copyright. All rights reserved. 
portfolios. Panel C of Table A1 reports the summary statistics for these decile groups. Extending the definitions of Tmi1 and Tmi10, we define TmiN where $N$ takes an integer value from 1 to 10 . TmiN represents the ownership of a firm held by institutional investors whose portfolios include the firm's stock in the decile $N$ group. We test the relation between Inef and TmiN by the 2SLS regression specification reported in Table A4.

Panel A and Panel B of Table A9 present the results of the second stage regressions. The dependent variables are Inef 1 in Panel A and Inef 2 in Panel B. The coefficients of TmiN follow a similar pattern in both Panel A and Panel B. The estimated coefficients of Tmi1-Tmi3 are negative and statistically significant, suggesting that institutional investors have a monitoring role in a firm's investment when the weighting of the firm's stock is among the top 30\% in their portfolios. The coefficient of Tmi4 is negative but statistically insignificant. In contrast, the estimated coefficients of Tmi5-Tmi10 are positive and statistically significant, suggesting that institutional investors have a lack of motivation to monitor a firm with a bottom $60 \%$ weighting ranking in their portfolios. In addition, the results show that the estimated coefficients of Tmi1-Tmi10 increase monotonically from negative to positive. Taken together, our results indicate that as monitoring motivation decreases, firm investment inefficiency increases. The monitoring motivation of institutional investors is not evenly allocated among all firms in institutional portfolios.

\subsection{Discussion of IV identification using the Russell index re- constitution}

The identification of our IVs is slightly different from that in Fich et al. (2015) and Schmidt and Fahlenbrach (2017). We do not include Russell's float-adjusted market cap-based rankings as IV in our 2SLS regressions. As indicated by Appel et al. (2016a), the float-adjusted market cap-based rankings are affected by insider ownership and liquid outstanding shares. The impact of the Russell index reconstitution on changes in IO may be over-stated if we include the rankings as IV. ${ }^{22}$ The other issue is that Russell adopted a "banding" rule to index assignment in 2007. ${ }^{23}$ Although we use the IV method instead of the regression discontinuity method (e.g., Chang et al., 2015) in our paper, we rerun the regressions reported in Table A4 in a restricted sample period 1995-2006.

${ }^{22}$ Please refer to Appel et al. (2016a) for detailed discussions.

${ }^{23}$ Please refer to Crane et al. (2016) for detailed discussions.

This article is protected by copyright. All rights reserved. 
5.5 Discussions of how motivated monitoring by institutional investors influences managerial decisions 5 FURTHER DISCUSSIONS AND ROBUSTNESS TESTS

Our untabulated test results are similar to those in Table A4.

\subsection{Discussions of how motivated monitoring by institutional investors influences managerial decisions}

In Section 5.1 and 5.2, we attribute the increase in investment efficiency to the monitoring of motivated institutional investors by revealing a more pronounced effect for over-investing firms with excess cash flows and under-investing firms subject to greater competitive pressures. In this section, we further discuss two other mechanisms by which motivated investors may influence managers' investment decisions. First, if institutional investors with motivation to monitor engage in closer monitoring, then these investors may be involved more in proxy voting. A recent study by Schwartz-Ziv and Wermers (2017) investigates the relation between institutional investors' voting on Say-On-Pay (SOP) proposals and their monitoring motivation. When firms implement SOP votes, "behind the scenes" discussions between firm managers and shareholders are particularly likely to occur (McCahery et al., 2016). Schwartz-Ziv and Wermers (2017) predict that institutional investors are more likely to focus on firms with a larger weight in their portfolio and to communicate with these firms' managers in private before the SOP voting. Consistent with this prediction, Schwartz-Ziv and Wermers (2017) find that higher portfolio weights lead to a greater support rate in SOP voting due to the communication before the voting. The finding in Schwartz-Ziv and Wermers (2017) provides us with direct evidence that the institutional investors' engagement with firm managers is positively related to their monitoring motivation.

The second potential mechanism that motivated monitoring by institutional investors improves firm governance is through forced $\mathrm{CEO}$ turnover. We collect forced CEO turnover data for all firms in the S\&P ExecuComp database during the period 19952005 from Eisfeldt and Kuhnen (2013). We find that for firms covered by ExecuComp, a higher motivated monitoring IO leads to a larger likelihood of forced CEO turnover in the next fiscal year, after controlling for industry and year fixed effects. This relation is robust for Tmil, Pmi1, $\operatorname{Ln}(1+N m i 1)$, and $T M A .^{24}$ A one standard deviation increase in Tmil1 is associated with a $0.25 \%$ decrease in the likelihood of future forced CEO turnover. Given that the unconditional sample mean of forced CEO turnover in ExecuComp is $1.4 \%$, the effect of Tmi1 on the forced CEO turnover probability is economically significant. Our results confirm that motivated monitoring by institutional

${ }^{24}$ Our results are available upon request.

This article is protected by copyright. All rights reserved. 
investors can influence management through the occurrences of forced CEO turnover.

\section{Conclusions}

Managers may potentially either under-invest or over-invest due to agency problems. Both types of inefficient investment may negatively impact firms' subsequent performance. Institutional investors may mitigate firm inefficient investment through monitoring and activism, thereby benefiting from the subsequent improved performance. However, the attention of institutional investors is limited (Kempf et al., 2017). If a firm represents only a very small proportion of institutional investors' portfolios, the opportunity cost of monitoring a firm may exceed the benefit of doing so. We therefore follow Fich et al. (2015) in measuring the motivation of an institutional investor to monitor a firm by the relative importance of the firm's stock in the institution's portfolio. We find that institutional investors with the greater motivation to monitor firm performance are associated with improved firm investment efficiency. By extending the measure of abnormal investment developed in Richardson (2006), we show that higher motivated monitoring IO is associated with inefficient investment (both too little and too much). A similar relation is not found between investors with the least motivation to monitor and firms' inefficient investment, a result that is consistent with the limited attention hypothesis.

Our paper sheds light on the ongoing debate on whether all types of institutional investors, including grey and passive ones, contribute to corporate governance. Our evidence suggests that as long as the holdings of a firm stock are important to institutional investors, even grey and passive institutional investors may improve firms' investment decisions. We also document the channels through which motivated institutional investors can mitigate inefficient investment. The role of investors' monitoring in reducing over-investment is stronger if firms have greater cash reserves and free cash flows, while the role of investors' monitoring in reducing under-investment is stronger when firm managers are more likely to have concerns about their future careers. Overall, our results establish a robust link between motivated monitoring by institutional investors and corporate investment efficiency.

This article is protected by copyright. All rights reserved. 


\section{References}

Abel, A.B., 1983. Optimal investment under uncertainty. The American Economic Review $73,228-233$.

Aghion, P., Reenen, J.V., Zingales, L., 2013. Innovation and institutional ownership. The American Economic Review 103, 277-304.

Almazan, A., Hartzell, J.C., Starks, L.T., 2005. Active institutional shareholders and costs of monitoring: Evidence from executive compensation. Financial Management $34,5-34$.

Appel, I., Gormley, T.A., Keim, D.B., 2016a. Identification using Russell 1000/2000 index assignments: A discussion of methodologies. Working Paper, Available at SSRN 2641548 .

Appel, I.R., Gormley, T.A., Keim, D.B., 2016b. Passive investors, not passive owners. Journal of Financial Economics 121, 111-141.

Asker, J., Farre-Mensa, J., Ljungqvist, A., 2015. Corporate investment and stock market listing: A puzzle? Review of Financial Studies 28, 342-390.

Balakrishnan, K., Core, J.E., Verdi, R.S., 2014. The relation between reporting quality and financing and investment: Evidence from changes in financing capacity. Journal of Accounting Research 52, 1-36.

Bertrand, M., Mullainathan, S., 2003. Enjoying the quiet life? Corporate governance and managerial preferences. Journal of Political Economy 111, 1043-1075.

Biddle, G.C., Hilary, G., Verdi, R.S., 2009. How does financial reporting quality relate to investment efficiency? Journal of Accounting and Economics 48, 112-131.

Blanchard, O.J., Lopez-de Silanes, F., Shleifer, A., 1994. What do firms do with cash windfalls? Journal of Financial Economics 36, 337-360.

Brickley, J.A., Lease, R.C., Jr., C.W.S., 1988. Ownership structure and voting on antitakeover amendments. Journal of Financial Economics 20, 267-291.

Brush, T.H., Bromiley, P., Hendrickx, M., 2000. The free cash flow hypothesis for sales growth and firm performance. Strategic Management Journal 21, 455-472.

This article is protected by copyright. All rights reserved. 
Bushee, B.J., 1998. The influence of institutional investors on myopic R\&D investment behavior. The Accounting Review 73, 305-333.

Cai, J., Zhang, Z., 2011. Leverage change, debt overhang, and stock prices. Journal of Corporate Finance 17, 391-402.

Chang, Y.C., Hong, H., Liskovich, I., 2015. Regression discontinuity and the price effects of stock market indexing. Review of Financial Studies 28, 212-246.

Chen, X., Harford, J., Li, K., 2007. Monitoring: Which institutions matter? Journal of Financial Economics 86, 279-305.

Cheng, M., Dhaliwal, D., Zhang, Y., 2013. Does investment efficiency improve after the disclosure of material weaknesses in internal control over financial reporting? Journal of Accounting and Economics Journal of Accounting and Economics 56, 1-18.

Crane, A.D., Michenaud, S., Weston, J.P., 2016. The effect of institutional ownership on payout policy: Evidence from index thresholds. Review of Financial Studies 29, $1-32$.

Cronqvist, H., Fahlenbrach, R., 2009. Large shareholders and corporate policies. Review of Financial Studies 22, 3941-3976.

Dittmar, A., Mahrt-Smith, J., 2007. Corporate governance and the value of cash holdings. Journal of Financial Economics 83, 599-634.

Eisfeldt, A.L., Kuhnen, C.M., 2013. CEO turnover in a competitive assignment framework. Journal of Financial Economics 109, 351-372.

Feltham, G.A., Ohlson, J.A., 1996. Uncertainty resolution and the theory of depreciation measurement. Journal of Accounting Research 34, 209-234.

Fich, E.M., Harford, J., Tran, A.L., 2015. Motivated monitors: The importance of institutional investors' portfolio weights. Journal of Financial Economics 118, 21-48.

Giannetti, M., Simonov, A., 2006. Which investors fear expropriation? Evidence from investors' portfolio choices. Journal of Finance 61, 1507-1547.

Gompers, P.A., Ishii, J.L., Metrick, A., 2003. Corporate governance and equity prices. Quarterly Journal of Economics 118, 107-155.

This article is protected by copyright. All rights reserved. 
Goodman, T.H., Neamtiu, M., Shroff, N., White, H.D., 2013. Management forecast quality and capital investment decisions. The Accounting Review 89, 331-365.

Gu, L., 2016. Product market competition, R\&D investment, and stock returns. Journal of Financial Economics 119, 441-455.

Gulen, H., Ion, M., 2016. Policy uncertainty and corporate investment. Review of Financial Studies 29, 523-564.

Harford, J., 1999. Corporate cash reserves and acquisitions. Journal of Finance 54, 1969-1997.

Hart, O.D., 1983. The market mechanism as an incentive scheme. The Bell Journal of Economics 14, 366-382.

Hayashi, F., 1982. Tobin's marginal q and average q: A neoclassical interpretation. Econometrica 50, 213-224.

Hennessy, C.A., 2004. Tobin's q, debt overhang, and investment. Journal of Finance 59, $1717-1742$.

Hubbard, R.G., 1998. Capital-market imperfections and investment. Journal of Economic Literature 36, 193-225.

Jensen, M.C., 1986. Agency costs of free cash flow, corporate finance, and takeovers. The American Economic Review 76, 323-329.

Jensen, M.C., Meckling, W.H., 1976. Theory of the firm: Managerial behavior, agency costs and ownership structure. Journal of Financial Economics 3, 305-360.

Kacperczyk, M., Van Nieuwerburgh, S., Veldkamp, L., 2016. A rational theory of mutual funds' attention allocation. Econometrica 84, 571-626.

Kempf, E., Manconi, A., Spalt, O.G., 2017. Distracted shareholders and corporate actions. Review of Financial Studies 30, 1660-1695.

Lang, L.H., Stulz, R.M., Walkling, R.A., 1991. A test of the free cash flow hypothesis: The case of bidder returns. Journal of Financial Economics 29, 315-335.

Lara, G., Juan, M., Garcia Osma, B., Penalva, F., 2016. Accounting conservatism and firm investment efficiency. Journal of Accounting and Economics 61, 221-238.

This article is protected by copyright. All rights reserved. 
Liu, C.Y., Low, A., Masulis, R., Zhang, L., 2016. Monitoring the monitor: Distracted institutional investors and board governance. Working Paper, Available at SSRN 2934755 .

Lou, X., Wang, A.Y., 2016. Flow-induced mispricing and corporate investment. Working Paper, Available at SSRN 2169135.

Malmendier, U., Tate, G., 2005. CEO overconfidence and corporate investment. Journal of Finance 60, 2661-2700.

Masulis, R.W., Mobbs, S., 2014. Independent director incentives: Where do talented directors spend their limited time and energy? Journal of Financial Economics 111, 406-429.

McCahery, J.A., Sautner, Z., Starks, L.T., 2016. Behind the scenes: The corporate governance preferences of institutional investors. Journal of Finance 71, 2905-2932.

McNichols, M.F., Stubben, S.R., 2008. Does earnings management affect firms' investment decisions? The Accounting Review 83, 1571-1603.

Modigliani, F., Miller, M.H., 1958. The cost of capital, corporation finance and the theory of investment. The American Economic Review 48, 261-297.

Mullins, W., 2014. The governance impact of index funds: Evidence from regression discontinuity. Working Paper, MIT Sloan School of Management.

Ohlson, J.A., 1995. Earnings, book values, and dividends in equity valuation. Contemporary Accounting Research 11, 661-687.

Petersen, M., 2009. Estimating standard errors in finance panel data sets: Comparing approaches. Review of Financial Studies 22, 435-480.

Porter, M.E., 1991. Capital disadvantage: America's failing capital investment system. Harvard Business Review 70, 65-82.

Richardson, S., 2006. Over-investment of free cash flow. Review of Accounting Studies 11, 159-189.

Schmidt, C., Fahlenbrach, R., 2017. Do exogenous changes in passive institutional ownership affect corporate governance and firm value? Journal of Financial Economics 124, 285-306.

This article is protected by copyright. All rights reserved. 
Schwartz-Ziv, M., Wermers, R., 2017. Do institutional investors monitor their large vs. small investments differently? Evidence from the Say-On-Pay vote. Working Paper, Available at SSRN 2510442 .

Shleifer, A., Vishny, R.W., 1997. A survey of corporate governance. Journal of Finance $52,737-783$.

Shroff, N., 2017. Corporate investment and changes in GAAP. Review of Accounting Studies 22, 1-63.

Sims, C.A., 2003. Implications of rational inattention. Journal of Monetary Economics 50, 665-690.

Stoughton, N.M., Wong, K.P., Yi, L., 2017. Investment efficiency and product market competition. Journal of Financial and Quantitative Analysis 52, 2611-2642.

Stulz, R., 1990. Managerial discretion and optimal financing policies. Journal of Financial Economics 26, 3-27.

Titman, S., Wei, K.J., Xie, F., 2004. Capital investments and stock returns. Journal of Financial and Quantitative Analysis 39, 677-700.

Wong, K.P., Yi, L., 2015. Institutional investors and corporate investment.Working Paper.

This article is protected by copyright. All rights reserved. 


\section{Appendix A}

\section{Table A1. Variable definitions}

This table provides variable definitions and corresponding data sources. CRSP refers to the Centre for Research in Security Prices, ISS refers to the Institutional Shareholder Services (formerly RiskMetrics), 13F refers to the Thomson Reuters 13F Database, and Bushee's website refers to http://acct.wharton.upenn.edu/faculty/bushee/IIclass.html.

\begin{tabular}{|c|c|c|}
\hline Variable & Definition & Source \\
\hline \multicolumn{3}{|c|}{ Investment regression variables } \\
\hline$A T$ & Total assets. & Compustat \\
\hline ITotal & $\begin{array}{l}\text { Annual total investment expenditure normalized by } A T \text { : } \\
{[\text { Capital expenditure }(\mathrm{CAPX})+\text { acquisition }} \\
\text { expenditure(AQC) }+\mathrm{R} \& \mathrm{D} \text { expenditure(XRD) - Receipts } \\
\text { from sale of property, plant and equipment(SPPE)]/AT } \\
\text { (Richardson, 2006). }\end{array}$ & Compustat \\
\hline IMaintenance & $\begin{array}{l}\text { Annual required investment expenditure to maintain assets } \\
\text { in place normalized by } A T \text { : } \\
\text { Depreciation and amortization(DPC)/AT (Richardson, } \\
2006 \text { ). }\end{array}$ & Compustat \\
\hline INew & $\begin{array}{l}\text { Annual investment expenditure on new projects normalized } \\
\text { by } A T \text { : ITotal - IMaintenance (Richardson, 2006). }\end{array}$ & Compustat \\
\hline$M V$ & $\begin{array}{l}\text { Market value of equity: price(PRCC_F }) * \text { common shares } \\
\text { outstanding (CSHO). }\end{array}$ & Compustat \\
\hline$V / P$ & $\begin{array}{l}\text { Growth opportunity: Assets in place } / M V \text {, where the assets } \\
\text { in place are estimated as }(1-\alpha r) B V+\alpha(1+r) X-\alpha r d \text {, } \\
\alpha=\omega / 1+r-\omega, r=12 \%, \omega=0.62, B V \text { is the book value of } \\
\text { equity(CEQ), } d \text { is annual dividend(DVC), and } X \text { is } \\
\text { operating income after depreciation(OIADP) (Ohlson, 1995; } \\
\text { Richardson, 2006). }\end{array}$ & Compustat \\
\hline Leverage & $\begin{array}{l}\text { Leverage ratio: the book value of total debt (long-term } \\
\text { debt(DLTT) }+ \text { short-term debt(DLC)) divided by the sum } \\
\text { of the book value of total debt and } B V \text { (Richardson, 2006). }\end{array}$ & Compustat \\
\hline Cash & $\begin{array}{l}\text { Cash holding ratio: cash and short-term investment(CHE) } \\
\text { divided by } A T \text { at the start of year (Richardson, 2006). }\end{array}$ & Compustat \\
\hline Age & $\begin{array}{l}\text { Firm age: the natural log of }(1+\text { the number of years the } \\
\text { firm has been listed on CRSP as of the start of year) } \\
\text { (Richardson, 2006). }\end{array}$ & CRSP \\
\hline Size & $\begin{array}{l}\text { The natural } \log \text { of } A T \text { at the start of year (Richardson, } \\
\text { 2006). }\end{array}$ & Compustat \\
\hline
\end{tabular}

This article is protected by copyright. All rights reserved. 
Table A1 - continued from previous page

\begin{tabular}{|c|c|c|}
\hline Variable & Definition & Source \\
\hline Return & $\begin{array}{l}\text { The percentage change of firm market value over the } \\
\text { previous year: } M V_{t} / M V_{t-1}-1 \text { (Richardson, 2006). }\end{array}$ & CRSP \\
\hline$M T B$ & $\begin{array}{l}\text { Market-to-book ratio: market value of asset } \\
(M V+\text { Total debt) divided by } A T \text { (Stoughton et al., 2017). }\end{array}$ & Compustat \\
\hline Tangibility & $\begin{array}{l}\text { Firm asset tangibility: } \\
\text { Property Plant and Equipment(PPENT)/AT (Stoughton } \\
\text { et al., 2017). }\end{array}$ & Compustat \\
\hline Ine $f 1$ & $\begin{array}{l}\text { Inefficient investment proxy variable: }|I N e w-\widehat{I N e w}| \text {, } \\
\text { where } \widehat{I N e w}_{t} \text { is estimated by historical panel regressions } \\
\text { between } 1982 \text { and year } t \text {. }\end{array}$ & $\begin{array}{l}\text { Compustat \& } \\
\text { CRSP }\end{array}$ \\
\hline$U n d 1$ & $\begin{array}{l}\text { Under-investment proxy variable: } U n d 1=\mid \text { Ine } f 1 \mid \text { if } \\
I N e w<\widehat{I N e w} \text {. }\end{array}$ & $\begin{array}{l}\text { Compustat \& } \\
\text { CRSP }\end{array}$ \\
\hline Ovr 1 & $\begin{array}{l}\text { Over-investment proxy variable: } \text { Ovr } 1=\mid \text { Ine } f 1 \mid \text { if } \\
I N e w>\widehat{I N e w} \text {. }\end{array}$ & $\begin{array}{l}\text { Compustat \& } \\
\text { CRSP }\end{array}$ \\
\hline Inef 2 & $\begin{array}{l}\text { Inefficient investment proxy variable: }|I N e w-\widehat{I N e w}| \\
\text { where } \widehat{I N e w} \text { is estimated by panel regressions between } 1995 \\
\text { and } 2015 \text { (Richardson, 2006). }\end{array}$ & $\begin{array}{l}\text { Compustat \& } \\
\text { CRSP }\end{array}$ \\
\hline$U n d 2$ & $\begin{array}{l}\text { Under-investment proxy variable: } U n d 2=\mid \text { Inef } 2 \mid \text { if } \\
I N e w<\widehat{I N e w} \text {. }\end{array}$ & $\begin{array}{l}\text { Compustat \& } \\
\text { CRSP }\end{array}$ \\
\hline Ovr 2 & $\begin{array}{l}\text { Over-investment proxy variable: Ovr } 2=\mid \text { Inef } 2 \mid \text { if } \\
I N e w>\widehat{I N e w} \text {. }\end{array}$ & $\begin{array}{l}\text { Compustat \& } \\
\text { CRSP }\end{array}$ \\
\hline
\end{tabular}

\section{Variables related to institutional investors}

Nmi1 Number of investors with motivation to monitor: number of

$13 \mathrm{~F}$ investors whose holding value in the firm is in the top $10 \%$ of their portfolios (Fich et al., 2015).

$N m i 10$ Number of investors who have the least motivation to monitor firms: number of investors whose holding value in the firm is in the bottom $10 \%$ of their portfolios.

Tmi1 Total firm ownership of investors with motivation to monitor $13 \mathrm{~F}$ (Fich et al., 2015).

Total firm ownership of investors who have the least

$13 \mathrm{~F}$ motivation to monitor firms.

Tmi1_Ind Total firm ownership of investors with motivation to monitor who are classified as independent institutional investors.

Tri1_Grey Total firm ownership of investors with motivation to monitor who are classified as grey institutional investors.

Tmi1_Tran Total firm ownership of investors with motivation to monitor who are classified as transient institutional investors.

Tmi1_NonTran Total firm ownership of investors with motivation to monitor who are classified as non-transient institutional investors.

Pmi1 Proportion of motivated institutional investors: ratio of Nmi1 to number of firm institutional investors.

This article is protected by copyright. All rights reserved. 
Table A1 - continued from previous page

\begin{tabular}{lcc}
\hline Variable & Definition & Source \\
\hline$T M A$ & Total institutional investor monitoring attention. & $13 \mathrm{~F}$ \\
Note: $I V$ is used as a prefix for all predicted institutional investor variables in 2 SLS regressions.
\end{tabular}

\section{IV in 2SLS regressions}

$R 1 T R 2$

Indicator variable: 1 if a firm switches from the Russell 1000

Bloomberg

to the Russell 2000 index, and 0 otherwise (Fich et al., 2015).

$R 2 T N \quad$ Indicator variable: 1 if a firm drops out of the Russell 2000

Bloomberg

index due to decrease in market value, and 0 otherwise (Fich

et al., 2015).

$R 2 T R 1 \quad$ Indicator variable: 1 if a firm switches from the Russell 2000

Bloomberg

to the Russell 1000 index, and 0 otherwise (Fich et al., 2015).

NTR2

Indicator variable: 1 if a firm gets newly included in the

Bloomberg

Russell 2000 index due to increase in market value, and 0

otherwise (Fich et al., 2015).

\section{Others}

Competition

Industry competition level is defined as 1 - Lerner ratio,

Compustat

where the Lerner ratio is the industry median gross margin

(Revenue(SALE) - Cost of goods sale(COGS))/Revenue.

Firms are assigned by 3-digit SIC codes (Aghion et al.,

2013).

G-index Numbers of anti-takeover provisions (Gompers et al., 2003).

ISS

FCF1 Free cash flow: Operatingcashflow $(O A N C F)-$

IMaintenance $+R \& D(X R D)-\widehat{I N e w}$, where $\widehat{I N e w}_{t}$ is

Compustat \& estimated by historical panel regressions between 1982 and year $t$.

FCF2 Free cash flow: Operatingcashflow $(O A N C F)-$ IMaintenance $+R \& D(X R D)-\widehat{I N e w}$, where $\widehat{I N e w}$ is CRSP estimated by panel regressions between 1995 and 2015 (Richardson, 2006).

This article is protected by copyright. All rights reserved. 


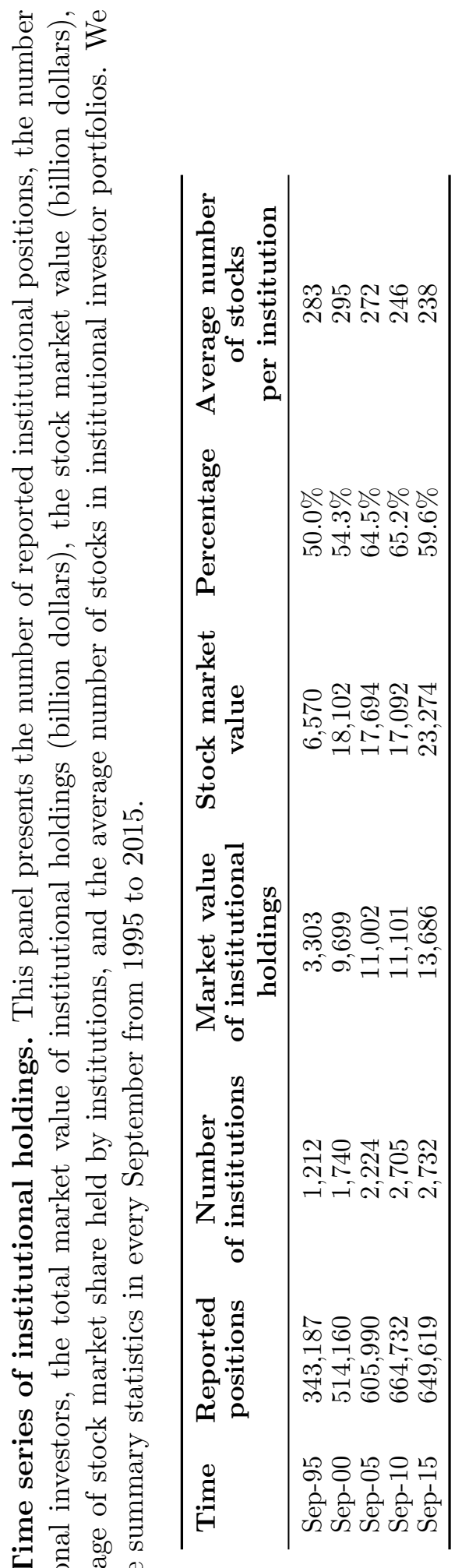

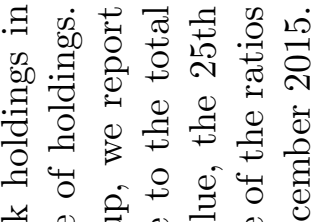

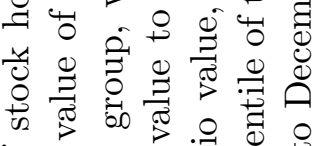

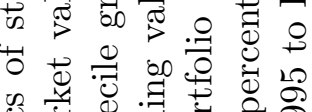

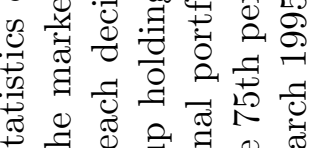
娄 年

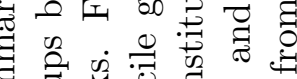
छ (5)

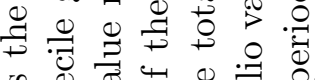

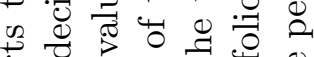
总. 挡

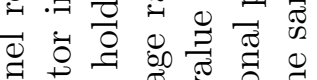

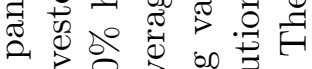
s. 光 i்

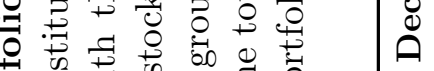

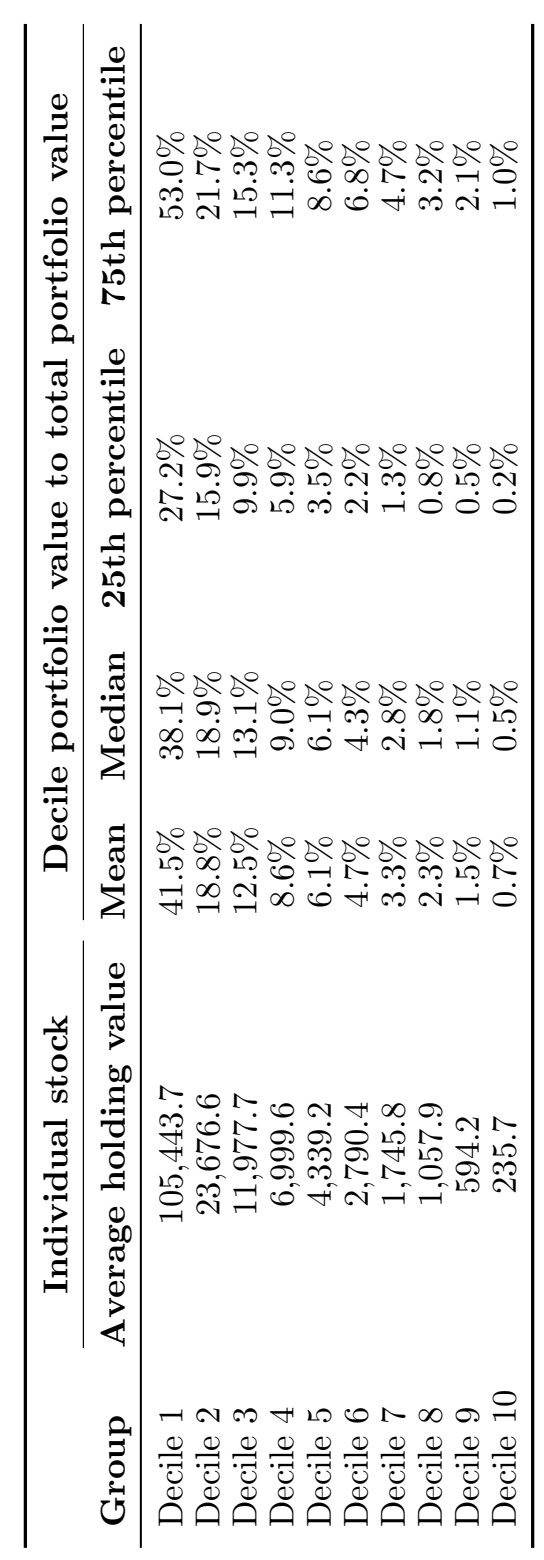

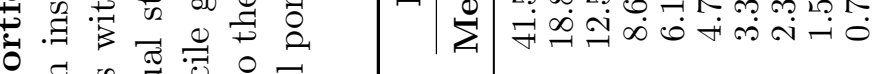

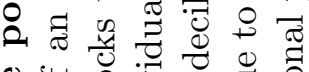

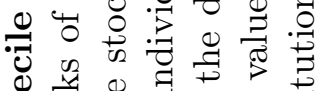

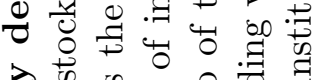

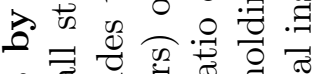
की

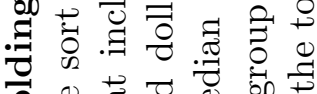

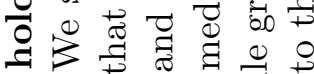

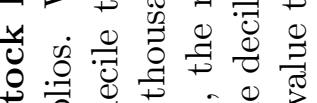
证

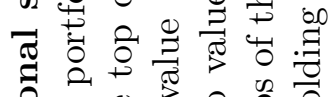
$.0 \%$

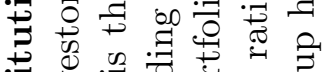

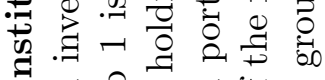

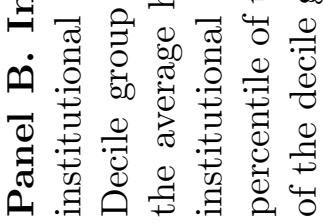

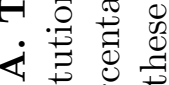

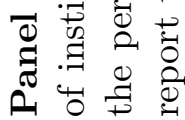

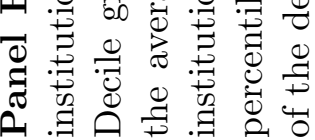

This article is protected by copyright. All rights reserved. 
Panel C. Main variables. This panel presents the descriptive statistics of the firm and institutional investor variables in our sample. The sample period is between 1995 and 2015 . All firms have complete information in the CRSP and Compustat databases. We also require that our sample firms have institutional ownership information from the Thomson Financial CDA/Spectrum Institutional $(13 \mathrm{~F})$ database. The number of observations, mean, standard deviation, minimum, 25th percentile, median, 75th percentile, and maximum are reported from left to right in sequence for each variable. Detailed definitions of all variables can be found in Appendix A.

\begin{tabular}{|c|c|c|c|c|c|c|c|c|}
\hline Variable & Obs. & Mean & S.D. & Min & $\mathrm{p} 25$ & Median & p75 & Max \\
\hline \multicolumn{9}{|c|}{ Investment regression variables } \\
\hline$A T$ & 92,546 & $2,648.1$ & $7,563.3$ & 2.3 & 62.2 & 265.5 & $1,302.2$ & $47,604.0$ \\
\hline ITotal & 92,546 & 0.15 & 0.15 & -0.03 & 0.05 & 0.10 & 0.20 & 0.74 \\
\hline IMaintenance & 92,546 & 0.05 & 0.04 & 0.00 & 0.03 & 0.04 & 0.06 & 0.24 \\
\hline INew & 92,546 & 0.10 & 0.15 & -0.18 & 0.00 & 0.05 & 0.14 & 0.71 \\
\hline$M V$ & 92,546 & $3,864.9$ & $17,935.9$ & 0.0 & 60.7 & 281.6 & $1,327.0$ & $630,000.0$ \\
\hline$V / P$ & 92,546 & 0.49 & 0.71 & -2.74 & 0.20 & 0.44 & 0.74 & 3.07 \\
\hline Leverage & 92,546 & 0.31 & 0.33 & 0.00 & 0.01 & 0.24 & 0.48 & 1.71 \\
\hline Cash & 92,546 & 0.22 & 0.30 & 0.00 & 0.02 & 0.10 & 0.30 & 1.59 \\
\hline Age & 92,546 & 2.24 & 1.01 & 0.00 & 1.61 & 2.30 & 3.00 & 4.19 \\
\hline Size & 92,546 & 5.35 & 2.46 & 0.00 & 3.79 & 5.36 & 7.01 & 10.69 \\
\hline Return & 92,546 & 0.21 & 0.85 & -0.87 & -0.25 & 0.00 & 0.39 & 4.48 \\
\hline$M T B$ & 92,546 & 1.86 & 1.81 & 0.27 & 0.83 & 1.25 & 2.10 & 11.10 \\
\hline Tangibility & 92,546 & 0.26 & 0.24 & 0.00 & 0.08 & 0.18 & 0.39 & 0.91 \\
\hline Excess Return_FF25 & 78,602 & -0.02 & 0.57 & -2.03 & -0.33 & -0.09 & 0.18 & 14.63 \\
\hline$I N e w-\widehat{I N e w}_{1}$ & 84,731 & 0.01 & 0.13 & -0.43 & -0.06 & -0.01 & 0.05 & 0.77 \\
\hline$I N e w-\widehat{I N e w}_{2}$ & 84,731 & 0.00 & 0.13 & -0.44 & -0.07 & -0.02 & 0.04 & 0.76 \\
\hline Inef 1 & 84,731 & 0.09 & 0.10 & 0.00 & 0.03 & 0.06 & 0.11 & 0.77 \\
\hline$U n d 1$ & 47,613 & 0.07 & 0.05 & 0.00 & 0.03 & 0.06 & 0.09 & 0.43 \\
\hline Ovr 1 & 37,118 & 0.11 & 0.13 & 0.00 & 0.03 & 0.06 & 0.15 & 0.77 \\
\hline Inef 2 & 84,731 & 0.09 & 0.09 & 0.00 & 0.03 & 0.06 & 0.11 & 0.76 \\
\hline$U n d 2$ & 47,613 & 0.08 & 0.05 & 0.00 & 0.04 & 0.07 & 0.10 & 0.44 \\
\hline Ovr2 & 37,118 & 0.10 & 0.13 & 0.00 & 0.02 & 0.05 & 0.13 & 0.76 \\
\hline \multicolumn{9}{|c|}{ Variables related to institutional investors } \\
\hline Tmi1 & 92,546 & 0.09 & 0.15 & 0.00 & 0.00 & 0.00 & 0.13 & 1.00 \\
\hline $\operatorname{Tmi} 10$ & 92,546 & 0.01 & 0.02 & 0.00 & 0.00 & 0.00 & 0.01 & 1.00 \\
\hline$N m i 1$ & 92,546 & 9.3 & 41 & 0 & 0 & 0 & 3 & 1,058 \\
\hline Nmi10 & 92,546 & 9.2 & 10 & 0 & 3 & 6 & 12 & 295 \\
\hline Tmi1_Ind & 92,546 & 0.07 & 0.11 & 0.00 & 0.00 & 0.00 & 0.10 & 1.00 \\
\hline Tmi1_Grey & 92,546 & 0.02 & 0.06 & 0.00 & 0.00 & 0.00 & 0.00 & 1.00 \\
\hline Tmi1_Tran & 92,546 & 0.02 & 0.05 & 0.00 & 0.00 & 0.00 & 0.03 & 1.00 \\
\hline Tmi1_NonTran & 92,546 & 0.06 & 0.12 & 0.00 & 0.00 & 0.00 & 0.08 & 1.00 \\
\hline Pmi1 & 92,546 & 0.03 & 0.06 & 0.00 & 0.00 & 0.00 & 0.04 & 1.00 \\
\hline$T M A$ & 92,546 & 2.46 & 1.70 & 0.00 & 0.85 & 2.68 & 3.75 & 9.09 \\
\hline \multicolumn{9}{|c|}{ Instrumental variables in 2SLS regressions } \\
\hline$R 1 T R 2$ & 94,648 & 0.01 & 0.10 & 0.00 & 0.00 & 0.00 & 0.00 & 1.00 \\
\hline$R 2 T N$ & 94,648 & 0.03 & 0.17 & 0.00 & 0.00 & 0.00 & 0.00 & 1.00 \\
\hline$R 2 T R 1$ & 94,648 & 0.01 & 0.11 & 0.00 & 0.00 & 0.00 & 0.00 & 1.00 \\
\hline NTR2 & 94,648 & 0.04 & 0.19 & 0.00 & 0.00 & 0.00 & 0.00 & 1.00 \\
\hline \multicolumn{9}{|l|}{ Others } \\
\hline Competition & 92,545 & 0.63 & 0.15 & 0.15 & 0.53 & 0.64 & 0.74 & 3.04 \\
\hline$G$-index & 7,317 & 8.94 & 2.66 & 1.00 & 7.00 & 9.00 & 11.00 & 17.00 \\
\hline \multirow{2}{*}{\multicolumn{6}{|c|}{ 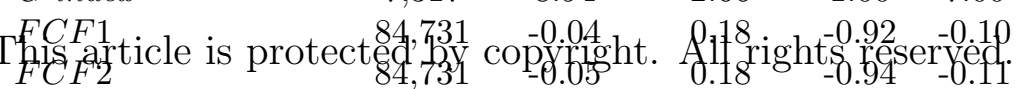 }} & -0.01 & 0.06 & 0.60 \\
\hline & & & & & & -0.02 & 0.05 & 0.50 \\
\hline
\end{tabular}




\section{Table A2. Optimal investment expenditure regressions}

This table reports the regression coefficients of the optimal investment expenditure model developed by Richardson (2006). The dependent variable is INew measured in year $t$. The independent variables are V/P, Leverage, Cash, Size, Return, Age, and INew $w_{t-1}$. Detailed definitions of these variables are described in Appendix A. In the historical panel regressions, we run a panel regression with firm-year observations between 1982 and year $t$, for each year $t$ in our sample period 1995-2015. We only report the time-series average of the coefficients estimated by twenty-one historical panel regressions. The numbers of positive and negative coefficients at the $1 \%$ statistical significance level are reported in parentheses. In the single panel regression, we run a panel regression over our sample period 1995-2015. The standard errors are clustered by firm in both regressions. $t$-values are reported in brackets. $* * *, * *$, and $*$ denote statistical significance at the $1 \%, 5 \%$, and $10 \%$ levels, respectively. Firm and year fixed effects are controlled in all regressions.

\begin{tabular}{|c|c|c|c|}
\hline \multicolumn{2}{|c|}{ Historical panel regressions } & \multicolumn{2}{|c|}{ Single panel regressions } \\
\hline $\bar{V}_{t-1}$ & $\begin{array}{c}-0.016 \\
(-21,+0)\end{array}$ & $\bar{V}_{t-1}$ & $\begin{array}{c}-0.021^{* * *} \\
{[-19.26]}\end{array}$ \\
\hline Leverage $_{t-1}$ & $\begin{array}{c}-0.091 \\
(-21,+0)\end{array}$ & Leverage $_{t-1}$ & $\begin{array}{c}-0.082^{* * *} \\
{[-24.76]}\end{array}$ \\
\hline Cash $_{t-1}$ & $\begin{array}{c}0.033 \\
(-0,+21)\end{array}$ & $\operatorname{Cash}_{t-1}$ & $\begin{array}{c}0.030 * * * \\
{[10.10]}\end{array}$ \\
\hline$S i z e_{t-1}$ & $\begin{array}{c}-0.008 \\
(-21,+0)\end{array}$ & Size $_{t-1}$ & $\begin{array}{c}-0.009 * * * \\
{[-18.42]}\end{array}$ \\
\hline Return $_{t-1}$ & $\begin{array}{c}0.009 \\
(-0,+21)\end{array}$ & Return $_{t-1}$ & $\begin{array}{c}0.007^{* * *} \\
{[11.35]}\end{array}$ \\
\hline$A g e_{t-1}$ & $\begin{array}{c}-0.011 \\
(-21,+0)\end{array}$ & $A g e_{t-1}$ & $\begin{array}{l}-0.002 \\
{[-1.01]}\end{array}$ \\
\hline$I N e w_{t-1}$ & $\begin{array}{c}0.115 \\
(-0,+21)\end{array}$ & $I N e w_{t-1}$ & $\begin{array}{c}0.124^{* * *} \\
{[19.24]}\end{array}$ \\
\hline Constant & $\begin{array}{c}0.166 \\
(-0,+21)\end{array}$ & Constant & $\begin{array}{c}0.166 * * * \\
{[50.69]}\end{array}$ \\
\hline Average Observation & 89,129 & Observations & 84,731 \\
\hline Average Adj. R-Squared & 0.208 & Adj. R-squared & 0.259 \\
\hline Year fixed effects & Yes & Year fixed effects & Yes \\
\hline Firm fixed effects & Yes & Firm fixed effects & Yes \\
\hline Number of historical panels & 21 & & \\
\hline
\end{tabular}

This article is protected by copyright. All rights reserved. 


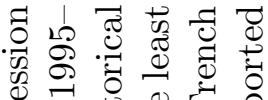

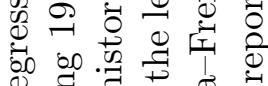

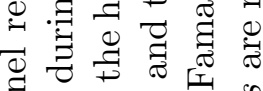

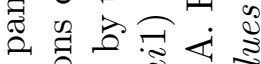

용 है है

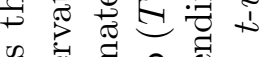

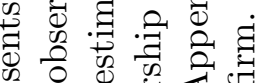

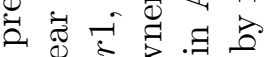

จ

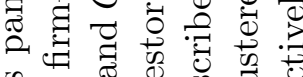

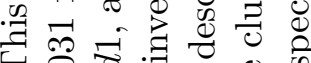

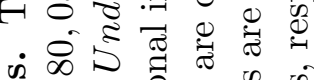

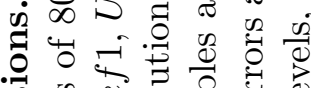

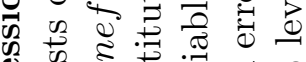

象

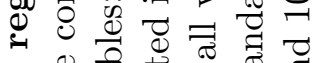

ब 0.

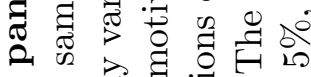

త్

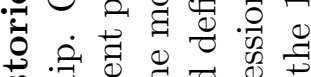

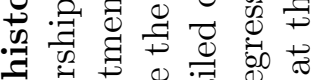

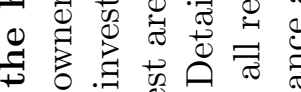

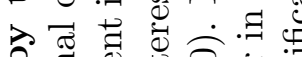

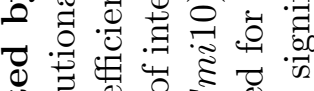

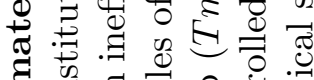

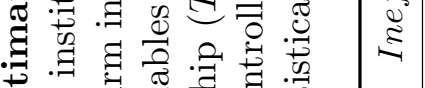

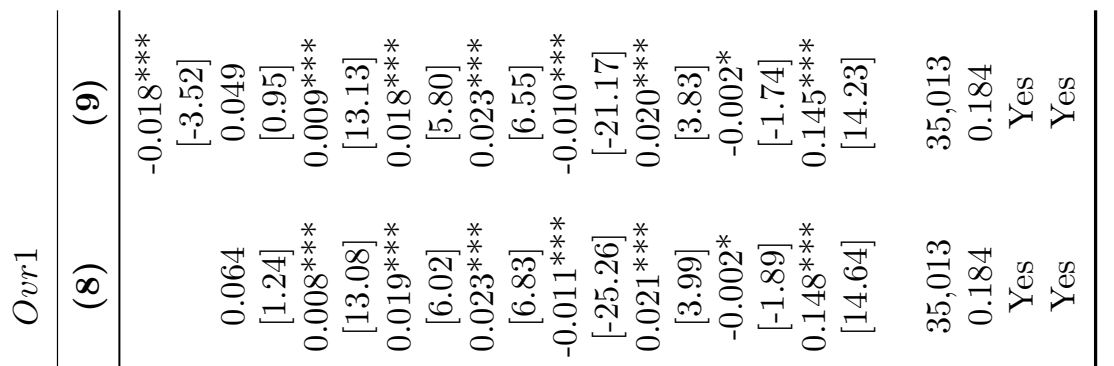

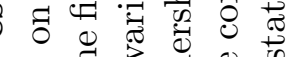

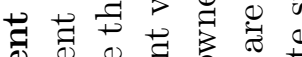

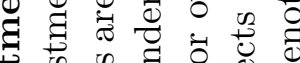

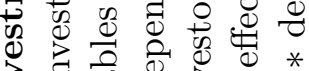

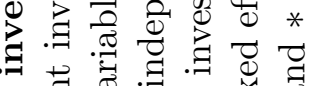

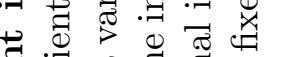

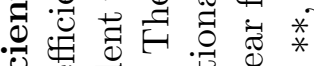

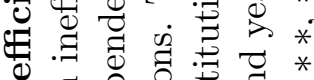

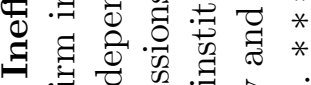

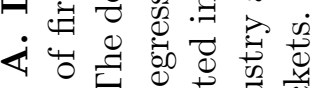

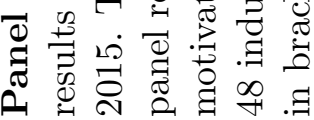

$\sqrt{3} \sqrt{5}$

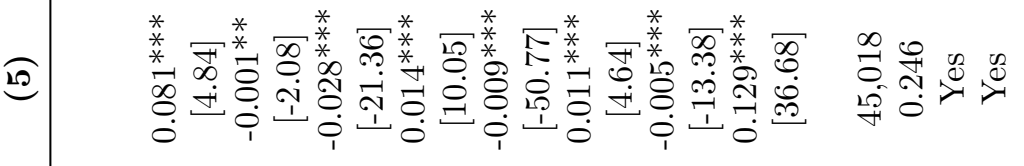

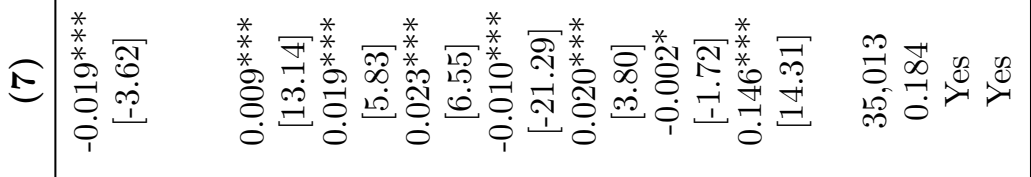

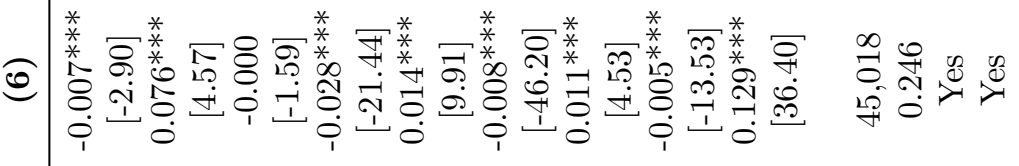

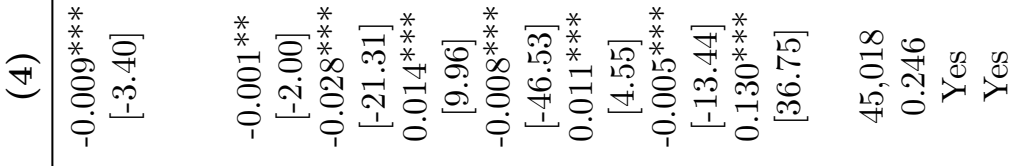

๙人|

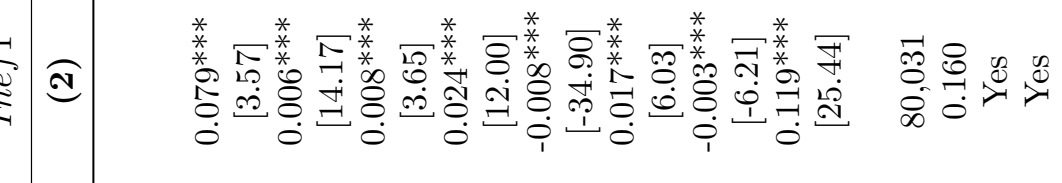

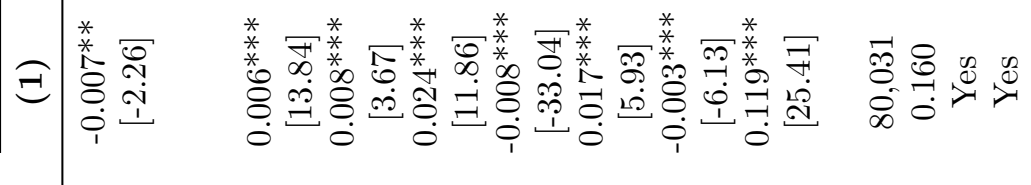

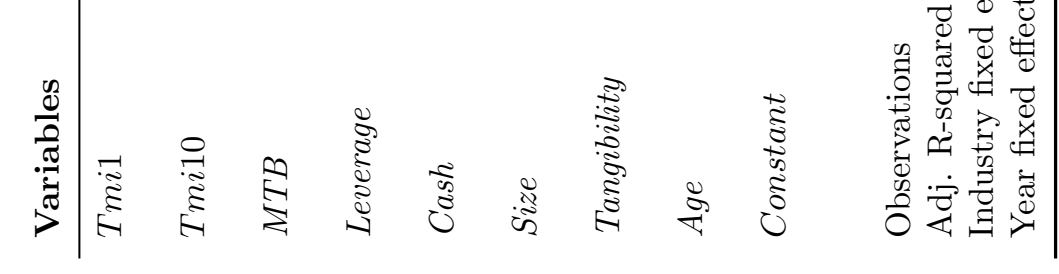

This article is protected by copyright. All rights reserved. 


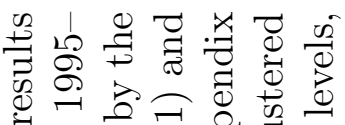

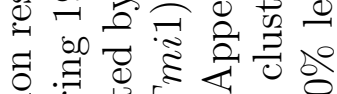
娄

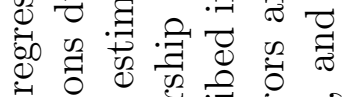

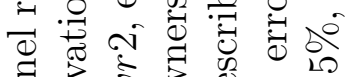

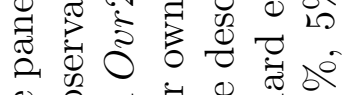

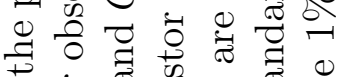

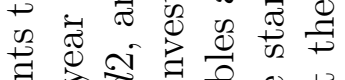

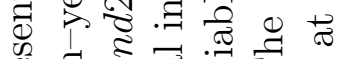
过 约 㐘

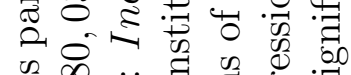

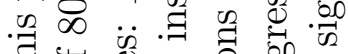

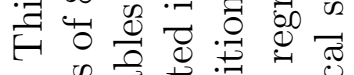

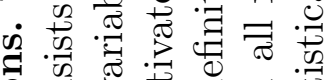

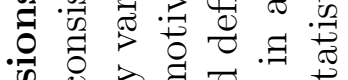

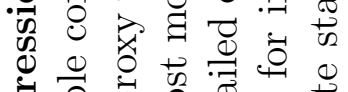

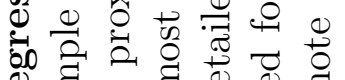

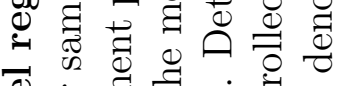
ब

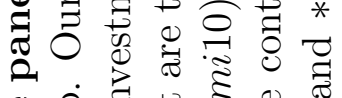

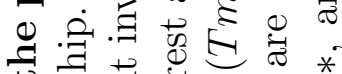
$\mp$ 击 ใิ

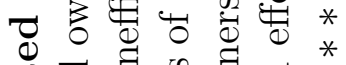

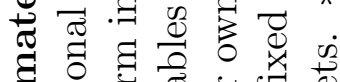
.

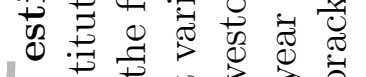

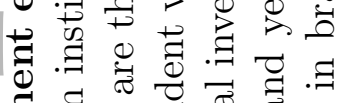

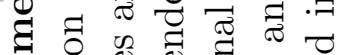

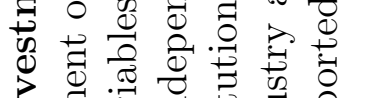

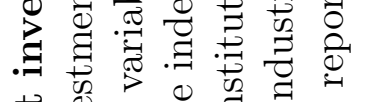

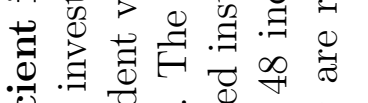

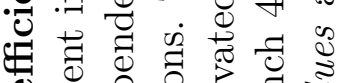
过

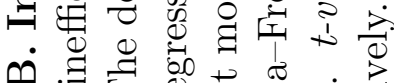
ต. .

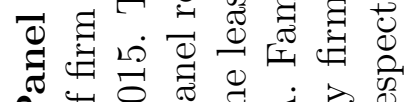

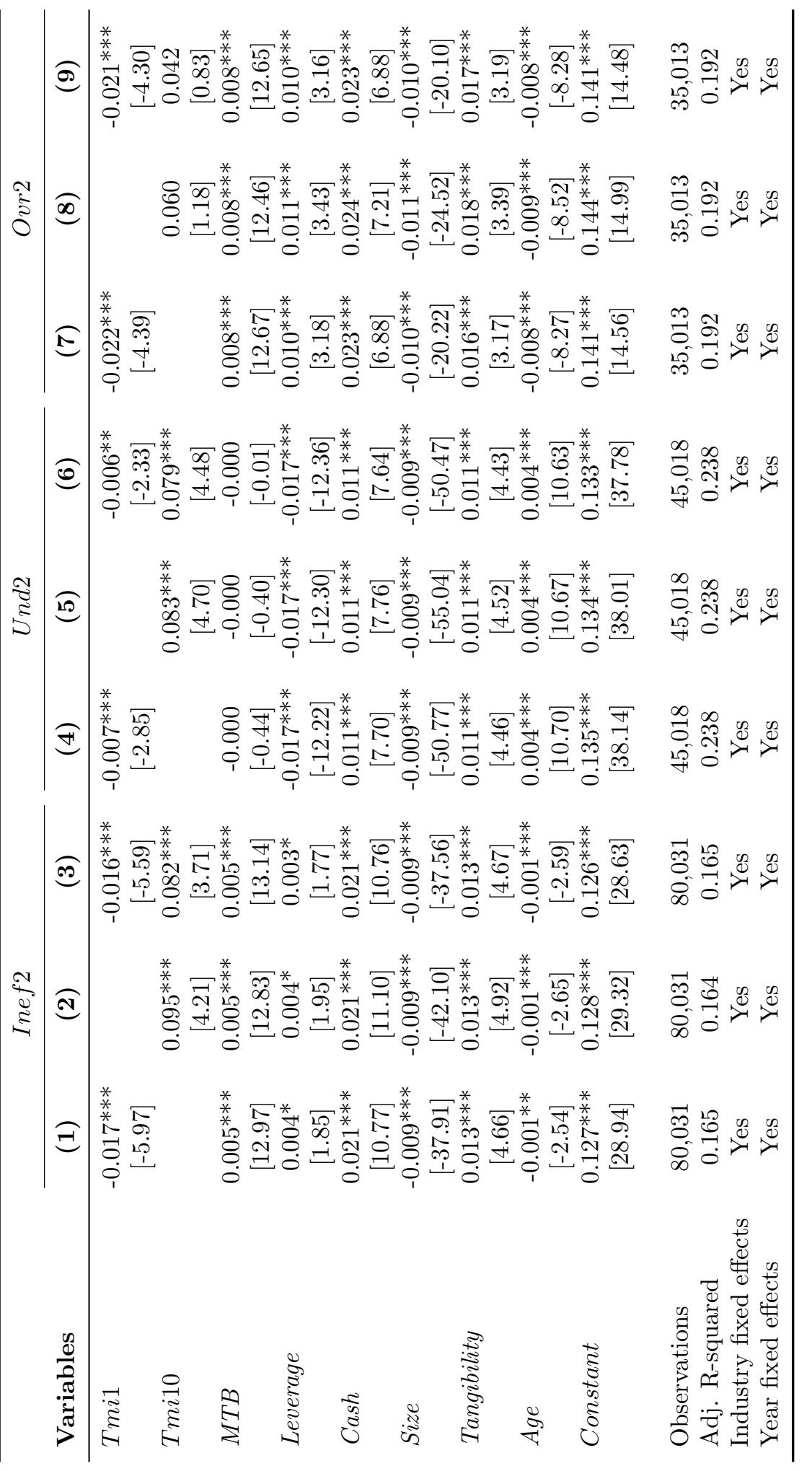

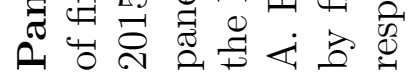

This article is protected by copyright. All rights reserved. 


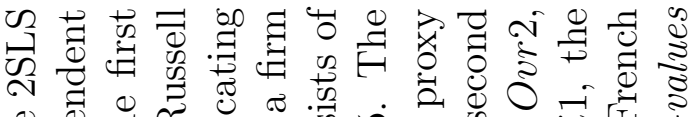

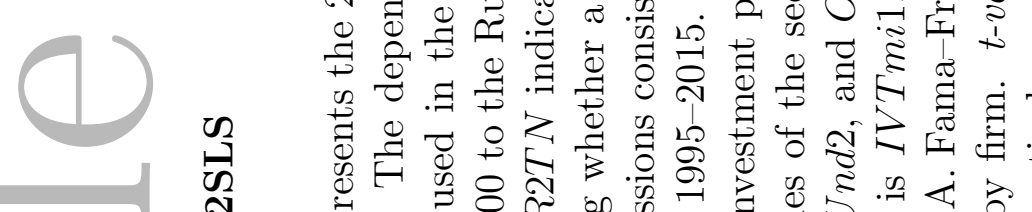

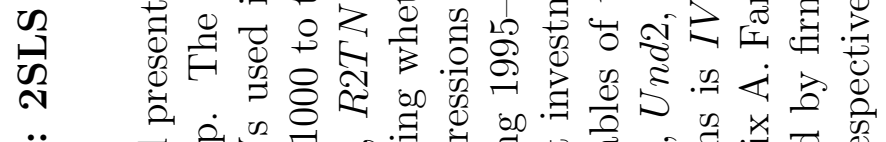

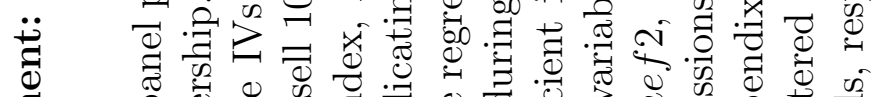

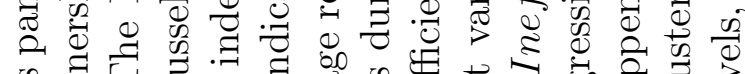
. 产 E.

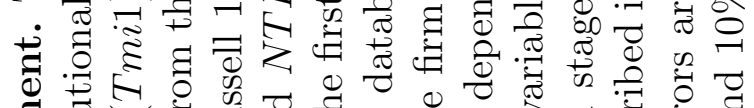

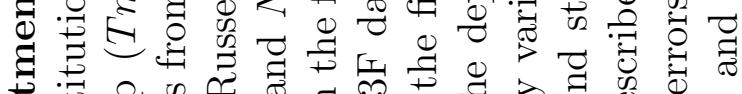

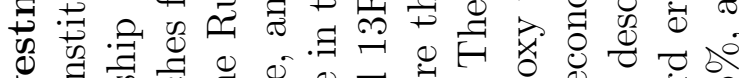

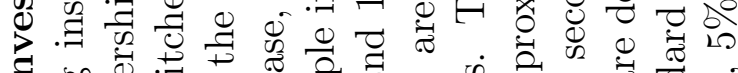

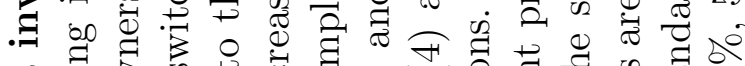

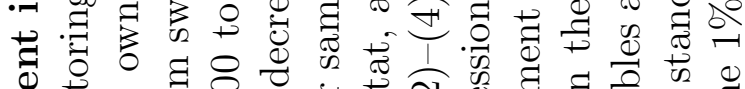

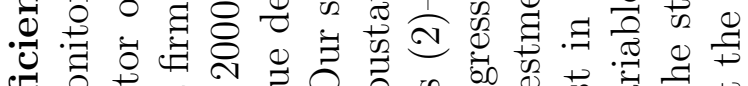

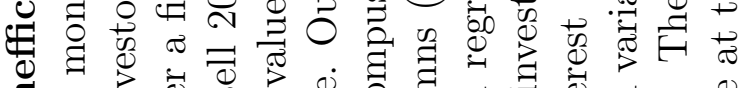

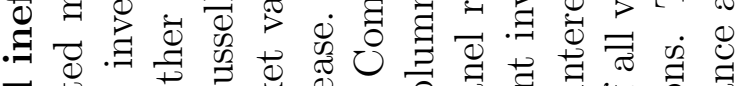

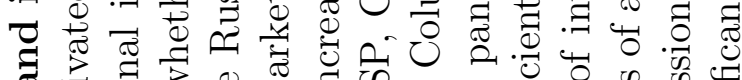

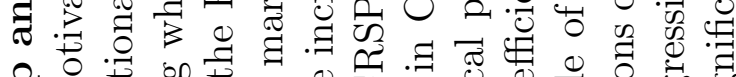

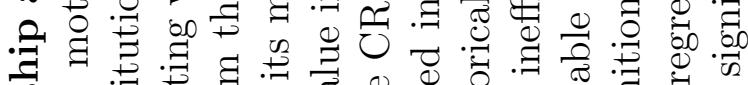

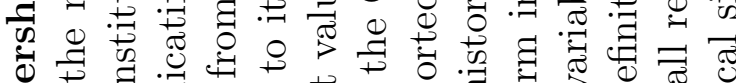

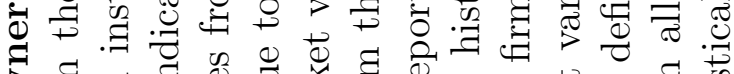

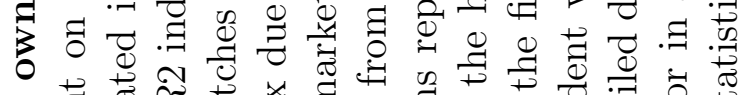

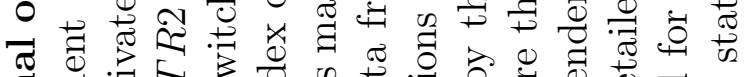

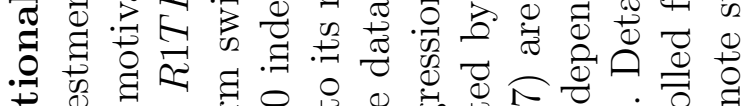

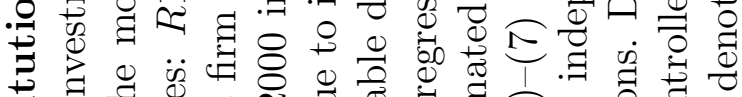

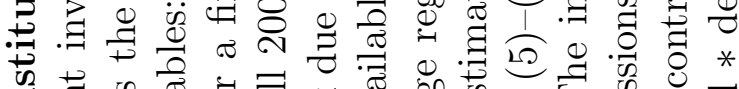

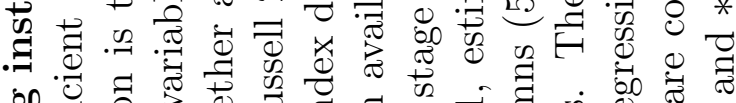

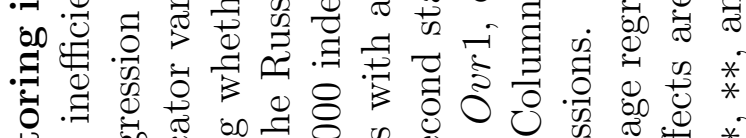
:

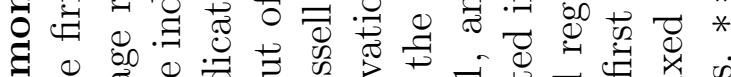

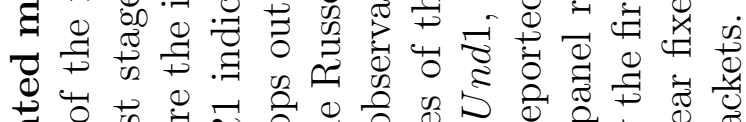

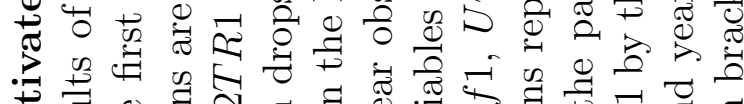

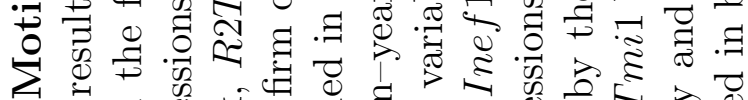

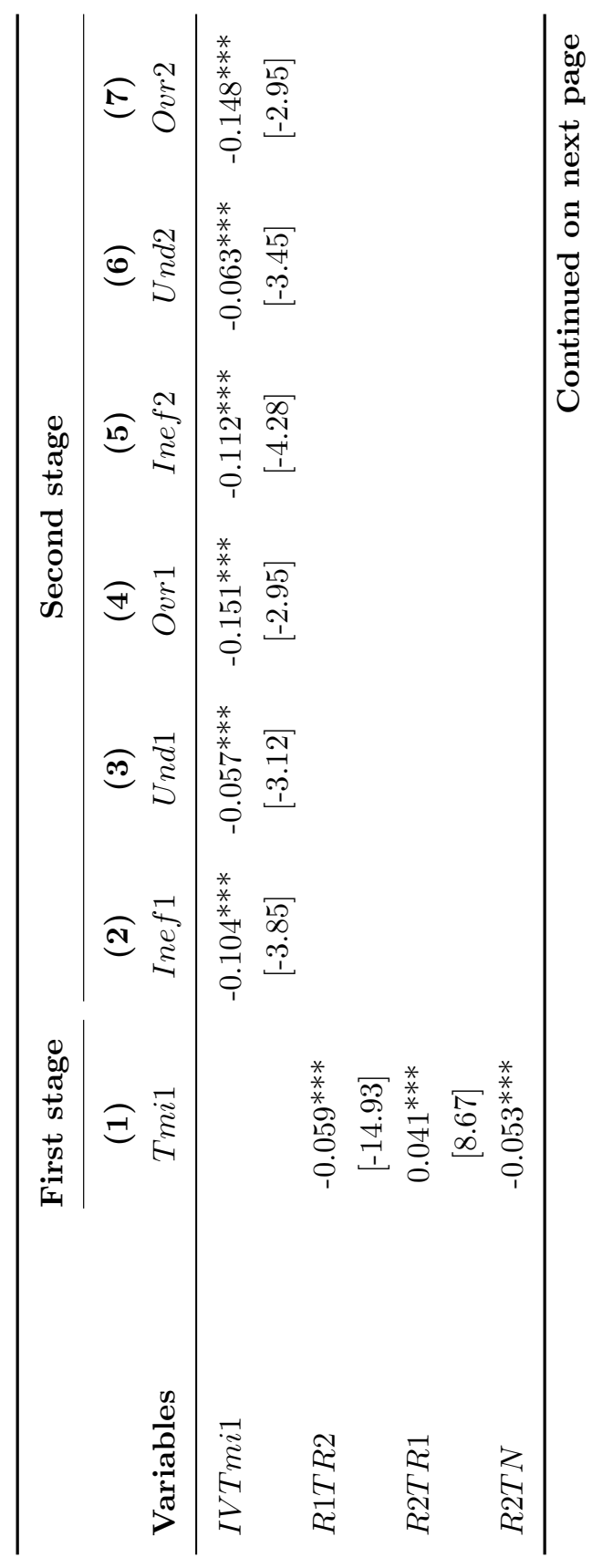

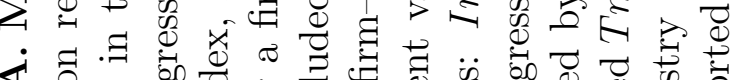

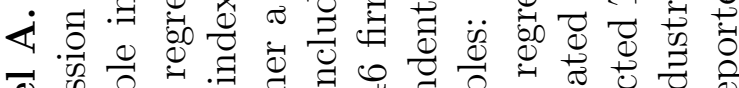

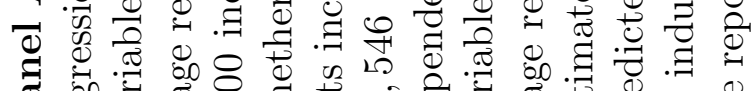

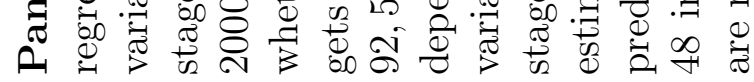

This article is protected by copyright. All rights reserved. 


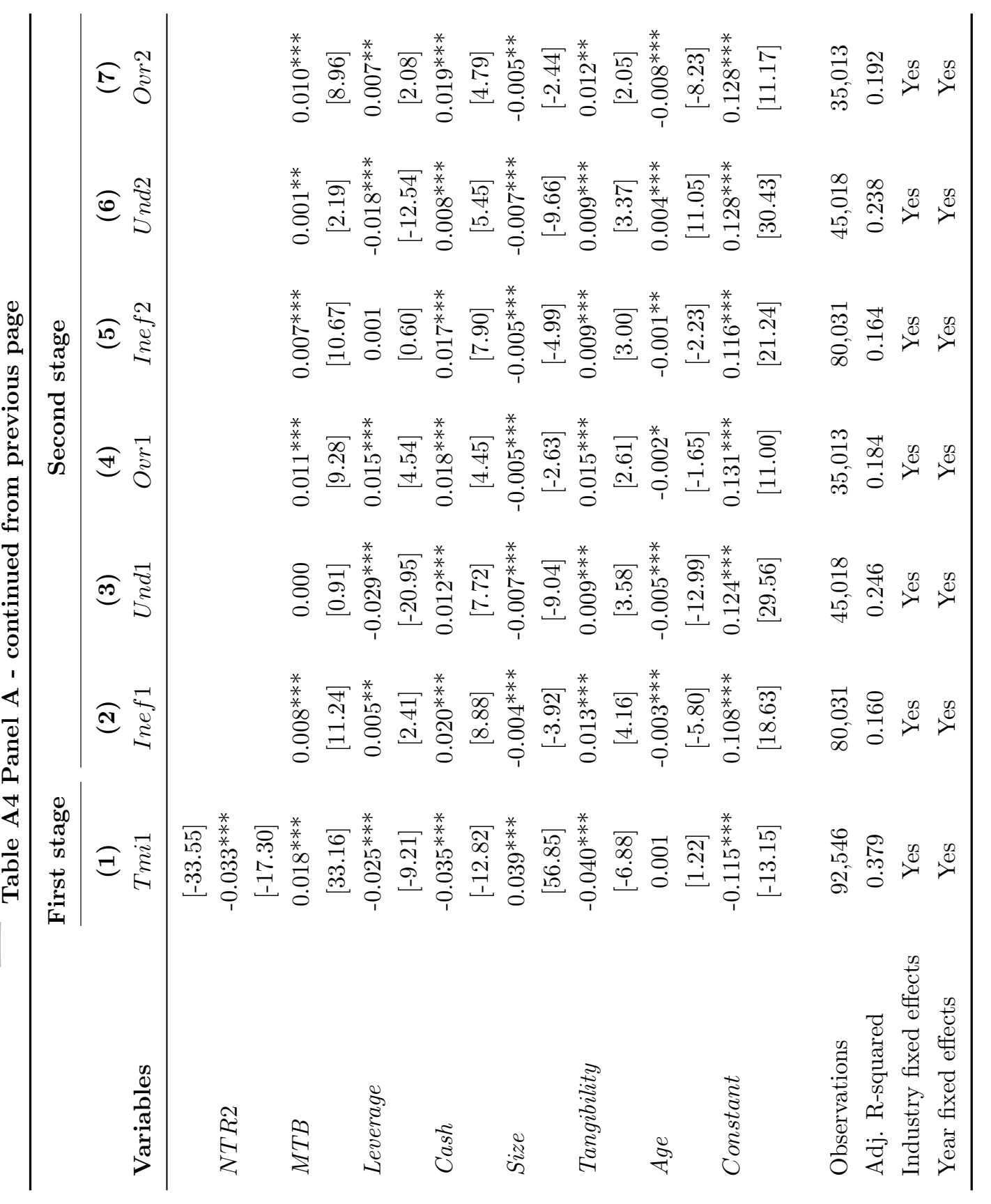

This article is protected by copyright. All rights reserved. 


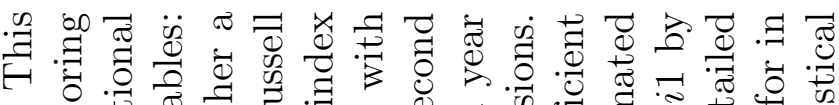
F

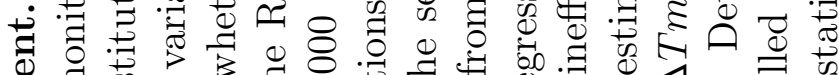
\&

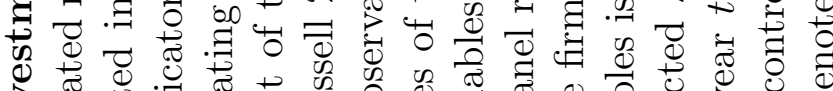

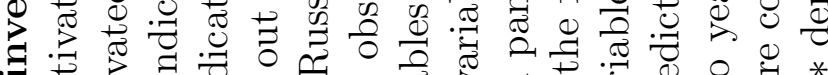
.

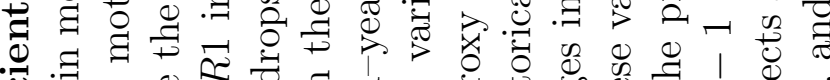

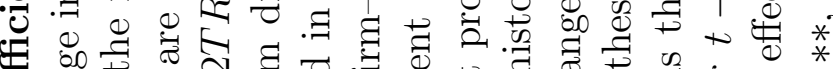

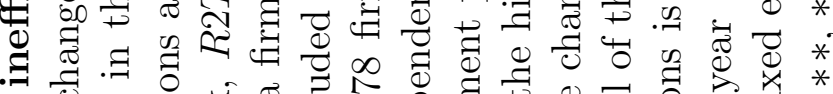

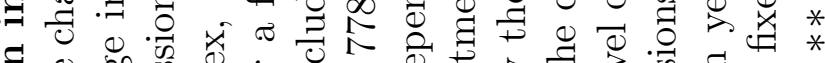

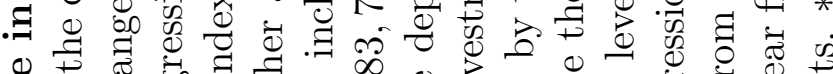
80 菏

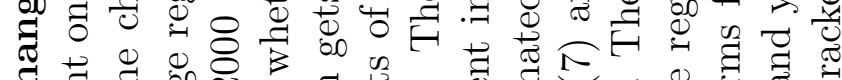

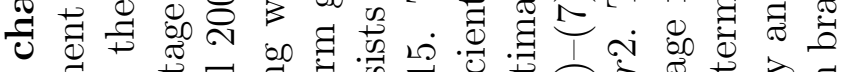

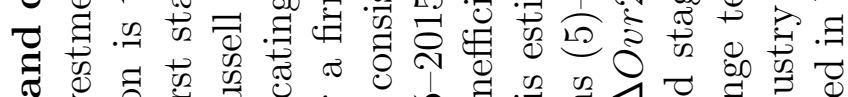
శ.

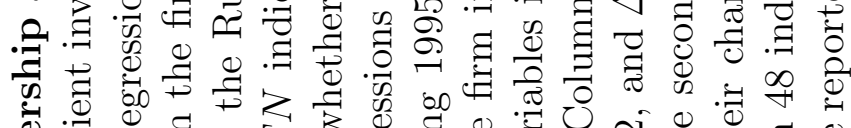

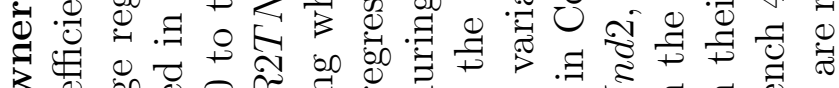

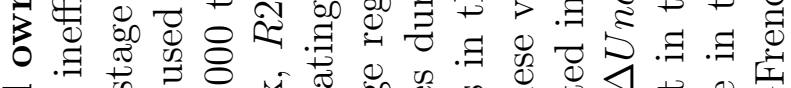

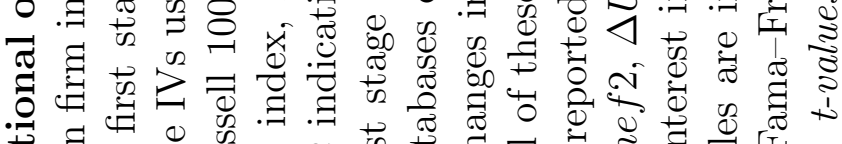

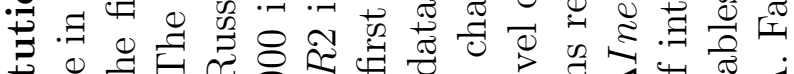

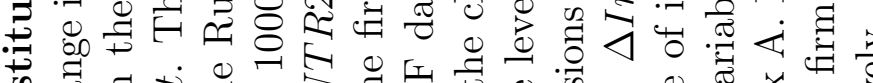

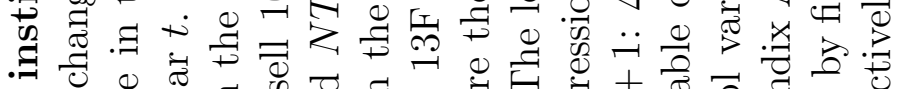

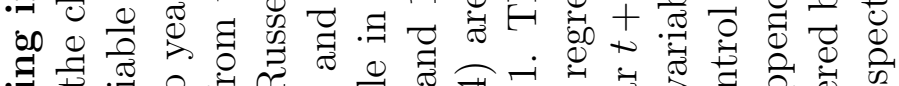

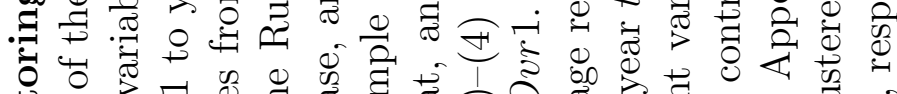

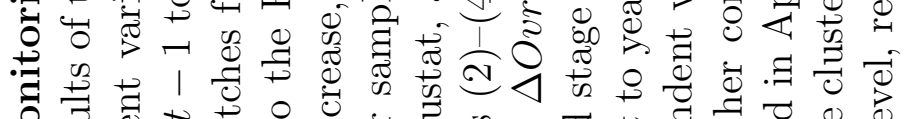

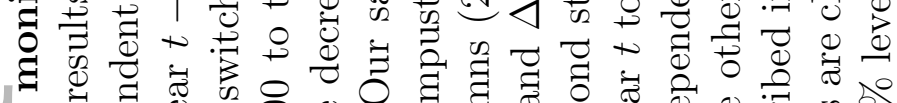
ర 元 .

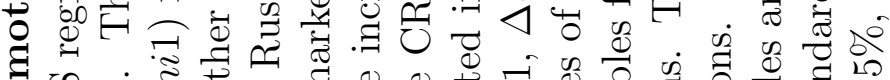

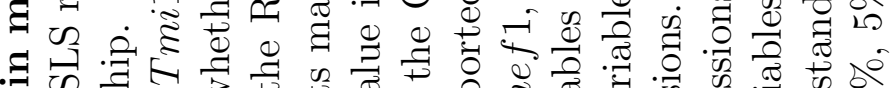

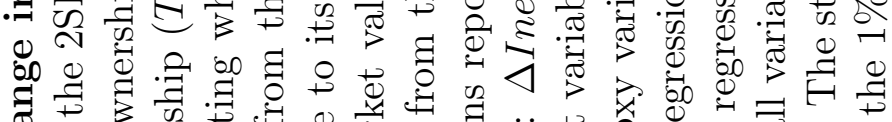

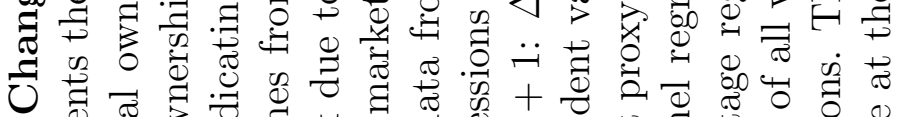

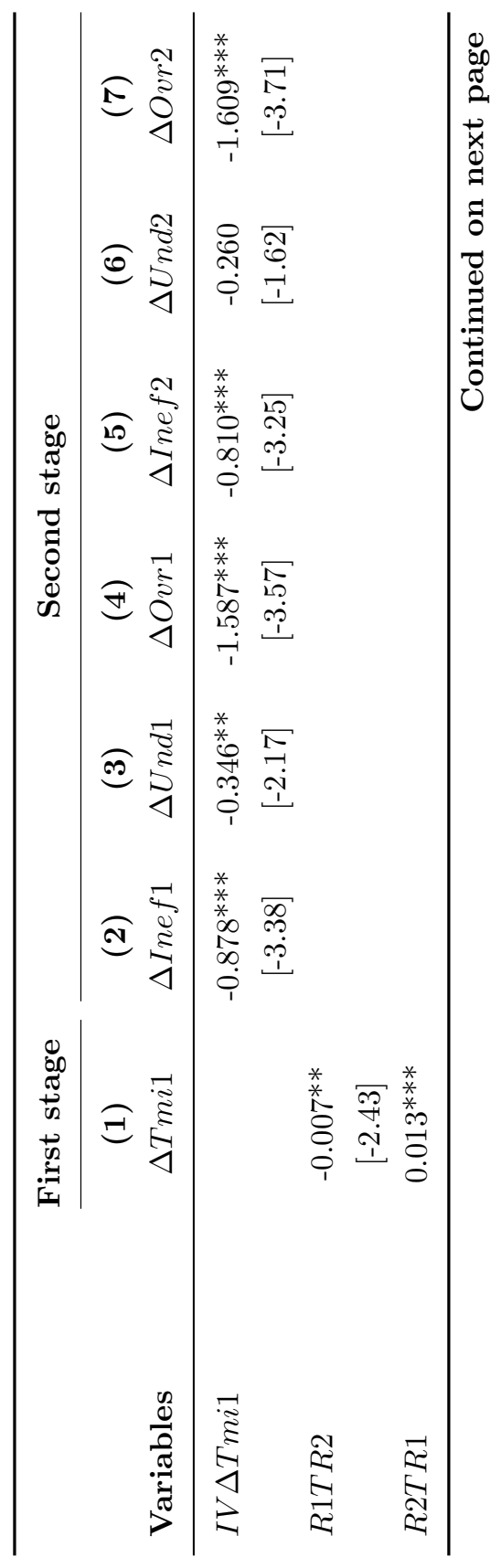
ต

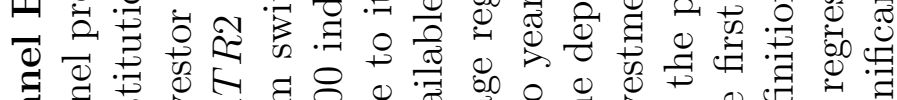

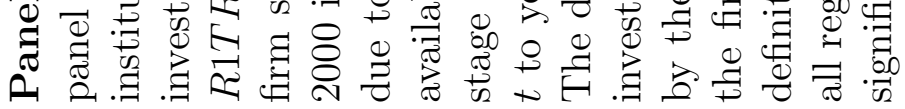

This article is protected by copyright. All rights reserved. 


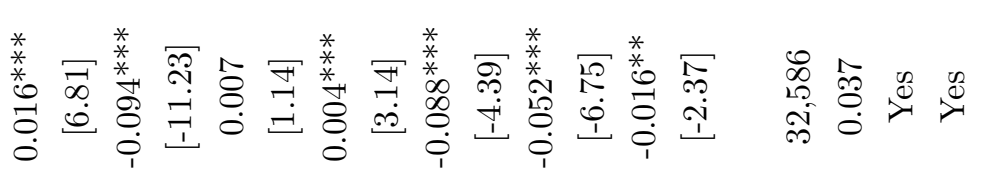

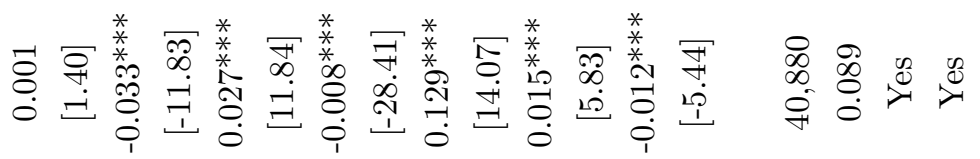

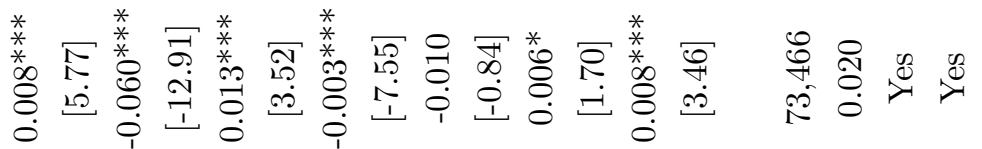

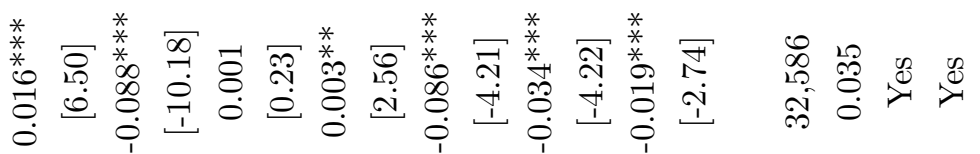

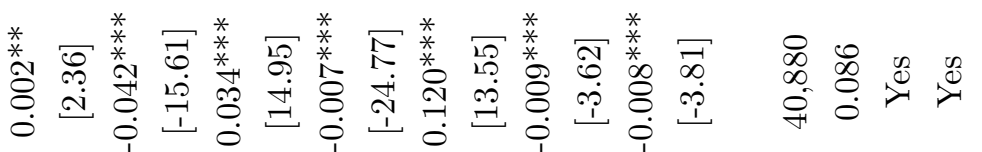

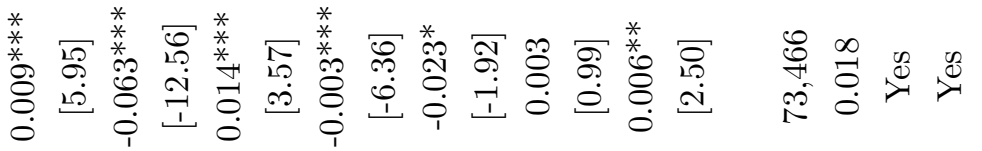
离

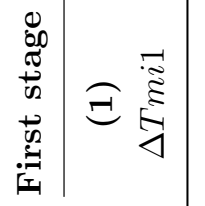

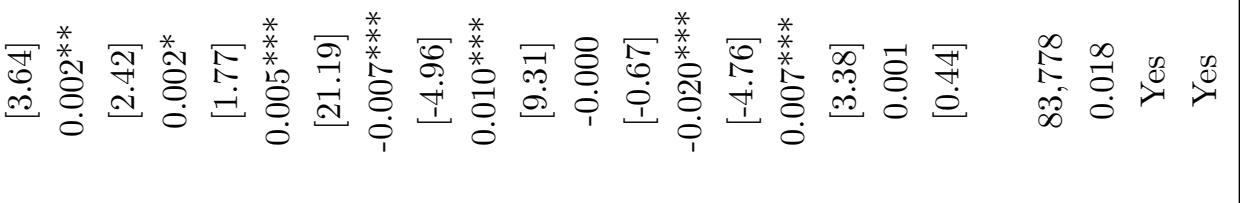

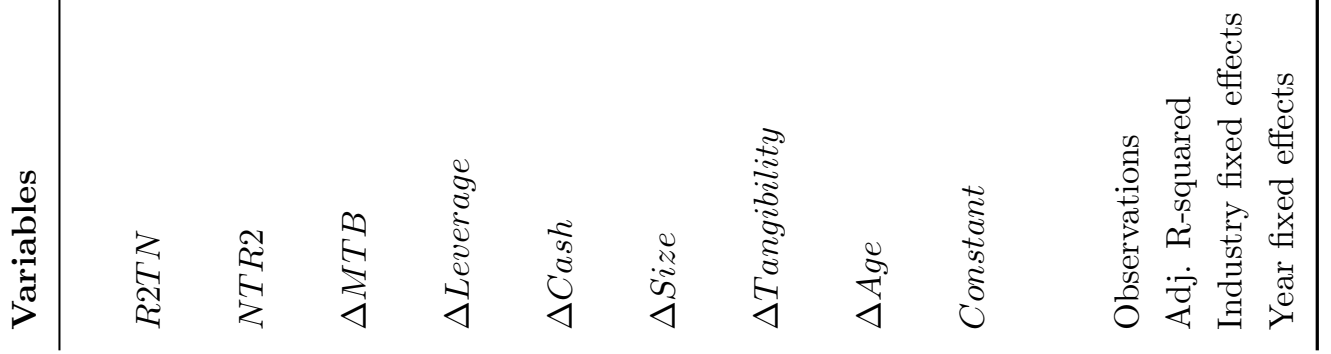
This article is protected by copyright. All rights reserved. 


\section{Table A5. Motivated monitoring institutional ownership by institution type}

This table presents the 2SLS regression results of firm inefficient investment on the different types of motivated monitoring institutional ownership. In Panel A and B, we divide Tmi1 into motivated monitoring independent institutional ownership Tmi1_Ind and motivated monitoring grey institutional ownership Tmi1_Grey. In Panel C and D, we divide Tmi1 into motivated monitoring transient institutional ownership Tmi1_Tran and motivated monitoring non-transient institutional ownership Tmi1_NonTran. In Panel $\mathrm{A}$ and $\mathrm{C}$, the dependent variables in the first stage regressions are the levels of motivated monitoring institutional ownership. In Panel B and D, the dependent variables in the first stage regressions are the changes in motivated monitoring institutional ownership, from year $t-1$ to year $t$. The independent variables of interest in the second stage regressions are the predicted ownership by the first stage regressions. In all four panels, the IVs used in the first stage regressions are the indicator variables: $R 1 T R 2$, R2TR1, R2TN, and NTR2. In Panel A and C (Panel B and D), our sample in the first stage regressions consists of 92,546 $(84,731)$ firm-year observations with available data from the CRSP, Compustat, and 13F databases during 1995-2015. In Panel A and C, the dependent variables in the second stage regressions are firm inefficient investment proxy variables Inef 1 estimated by the historical panel regressions and Ine 2 estimated by the single panel regression. In Panel $\mathrm{B}$ and $\mathrm{D}$, the dependent variables in the second stage regressions are the changes in the firm inefficient investment proxy variables from year $t$ to year $t+1: \Delta$ Inef 1 and $\Delta$ Inef2. All the control variables are the same as those reported in Table A4 and their estimated coefficients are suppressed for brevity. Detailed definitions of all variables are described in Appendix A. Fama-French 48 industry and year fixed effects are controlled for in all regressions. The standard errors are clustered by firm. $t$-values are reported in brackets. $* * *, * *$, and $*$ denote statistical significance at the $1 \%, 5 \%$, and $10 \%$ level, respectively.

\begin{tabular}{lcccc}
\hline \multicolumn{1}{c}{$(\mathbf{1})$} & $(\mathbf{2})$ & $(\mathbf{3})$ & $(\mathbf{4})$ \\
Variables & Inef1 & Inef2 & Inef1 & Inef2 \\
\hline Panel A. Independent vs. grey investors & & \\
IVTmi1_Ind & $-0.140^{* * *}$ & $-0.112^{* * *}$ & & \\
& {$[-3.95]$} & {$[-4.28]$} & & \\
IVTmi1_Grey & & & $-0.281^{* * *}$ & $-0.309^{* * *}$ \\
& & & {$[-3.12]$} & {$[-3.58]$} \\
Control variables & Yes & Yes & Yes & Yes \\
Industry \& year fixed effects & Yes & Yes & Yes & Yes \\
Observations & 80,031 & 80,031 & 80,031 & 80,031 \\
Adj. R-squared & 0.160 & 0.164 & 0.160 & 0.164 \\
& & & & \\
\hline
\end{tabular}

Continued on next page

This article is protected by copyright. All rights reserved. 
Table A5 - continued from previous page

\begin{tabular}{|c|c|c|c|c|}
\hline Variables & $\begin{array}{c}(\mathbf{1}) \\
\text { Inef } 1\end{array}$ & $\begin{array}{c}(2) \\
\text { Inef } 2\end{array}$ & $\begin{array}{c}(3) \\
\text { Inef1 }\end{array}$ & $\begin{array}{c}(4) \\
\text { Inef2 }\end{array}$ \\
\hline \multicolumn{5}{|c|}{ Panel B. Change in independent vs. change in grey investors } \\
\hline IV $\Delta$ Tmi1_Ind & $\begin{array}{c}-1.068^{* * *} \\
{[-3.48]}\end{array}$ & $\begin{array}{c}-0.972^{* * *} \\
{[-3.31]}\end{array}$ & & \\
\hline IV $\Delta$ Tmi1_Grey & & & $\begin{array}{c}-1.647^{* *} \\
{[-2.18]}\end{array}$ & $\begin{array}{c}-1.592^{* *} \\
{[-2.25]}\end{array}$ \\
\hline Control variables & Yes & Yes & Yes & Yes \\
\hline Industry \& year fixed effects & Yes & Yes & Yes & Yes \\
\hline Observations & 73,466 & 73,466 & 73,466 & 73,466 \\
\hline Adj. R-squared & 0.018 & 0.020 & 0.018 & 0.020 \\
\hline \multicolumn{5}{|c|}{ Panel C. Transient vs. non-transient investors } \\
\hline IVTmi1_Tran & $\begin{array}{c}-0.237^{* * *} \\
{[-3.62]}\end{array}$ & $\begin{array}{c}-0.245^{* * *} \\
{[-3.90]}\end{array}$ & & \\
\hline IVTmi1_NonTran & & & $\begin{array}{c}-0.132^{* * *} \\
{[-3.50]}\end{array}$ & $\begin{array}{c}-0.143^{* * *} \\
{[-3.95]}\end{array}$ \\
\hline Control variables & Yes & Yes & Yes & Yes \\
\hline Industry \& year fixed effects & Yes & Yes & Yes & Yes \\
\hline Observations & 80,031 & 80,031 & 80,031 & 80,031 \\
\hline Adj. R-squared & 0.160 & 0.164 & 0.160 & 0.164 \\
\hline \multicolumn{5}{|c|}{ Panel D. Change in transient vs. change in non-transient investors } \\
\hline IV $\Delta T$ Tmi1_Tran & $\begin{array}{c}-2.140 * * * \\
{[-3.92]}\end{array}$ & $\begin{array}{c}-1.910 * * * \\
{[-3.65]}\end{array}$ & & \\
\hline IV $\Delta$ Tmi1_NonTran & & & $\begin{array}{c}-1.421^{* * *} \\
{[-3.57]}\end{array}$ & $\begin{array}{c}-1.298^{* * *} \\
{[-3.42]}\end{array}$ \\
\hline Control variables & Yes & Yes & Yes & Yes \\
\hline Industry \& year fixed effects & Yes & Yes & Yes & Yes \\
\hline Observations & 73,466 & 73,466 & 73,466 & 73,466 \\
\hline Adj. R-squared & 0.018 & 0.020 & 0.018 & 0.020 \\
\hline
\end{tabular}

This article is protected by copyright. All rights reserved. 


\section{Table A6. Alternative measures of motivated monitoring institutional owner- ship}

This table presents the 2SLS regression results of inefficient investment on alternative measures of motivated monitoring institutional ownership: Pmi1 the proportion of motivated monitoring institutional investors in a firm's institutional investors, $\operatorname{Ln}(1+N m i 1)$ the natural $\log$ of one plus the motivated institutional investor number (Nmi1), and $T M A$ calculated by Equation (4). The 2SLS regression model is the same as those reported in Panel A of Table A4. We omit the estimated regression coefficients in the first step regression for brevity. In Panel A-C, the independent variable of interest in the second stage regressions is $I V P m i 1, I V L n(1+N m i 1)$, and $I V T M A$, the predicted values by the first stage regressions. We suppress the estimated coefficients of all control variables for brevity. Detailed definitions of all variables are described in Appendix A. Fama-French 48 industry and year fixed effects are controlled for in all regressions. The standard errors are clustered by firm. $t$-values are reported in brackets. $* * *, * *$, and $*$ denote statistical significance at the $1 \%, 5 \%$, and $10 \%$ level, respectively.

\begin{tabular}{lcccccc}
\hline \multicolumn{1}{l}{ Variables } & $(\mathbf{1})$ & $\mathbf{( 2 )}$ & $\mathbf{( 3 )}$ & $\mathbf{( 4 )}$ & $\mathbf{( 5 )}$ & $\mathbf{( 6 )}$ \\
\hline Panel A. Pmi1 & Inef1 & Und1 & Ovr 1 & Inef2 & Und2 & Ovr 2 \\
IVPmi1 & \multicolumn{7}{c}{} \\
& $-0.265^{* * *}$ & $-0.145^{* * *}$ & $-0.392^{* * *}$ & $-0.288^{* * * *}$ & $-0.172^{* * *}$ & $-0.382^{* * *}$ \\
& {$[-3.41]$} & {$[-2.84]$} & {$[-2.63]$} & {$[-3.87]$} & {$[-3.33]$} & {$[-2.62]$} \\
Control variables & & & & & & \\
Industry \& year fixed effects & Yes & Yes & Yes & Yes & Yes & Yes \\
Observations & 80,031 & 45,018 & 35,013 & 80,031 & 45,018 & 35,013 \\
Adj. R-squared & 0.160 & 0.246 & 0.184 & 0.164 & 0.238 & 0.192
\end{tabular}

Panel B. Ln(1+Nmi1)

$\begin{array}{lcccccc}\text { IVLn }(1+N m i 1) & -0.011^{* * *}-0.006^{* * *} & -0.016^{* * *} & -0.012^{* * *} & -0.007^{* * *} & -0.015^{* * *} \\ & {[-4.11]} & {[-3.33]} & {[-3.04]} & {[-4.49]} & {[-3.54]} & {[-3.03]} \\ & & & & & & \\ \text { Control variables } & \text { Yes } & \text { Yes } & \text { Yes } & \text { Yes } & \text { Yes } & \text { Yes } \\ \text { Industry \& year fixed effects } & \text { Yes } & \text { Yes } & \text { Yes } & \text { Yes } & \text { Yes } & \text { Yes } \\ \text { Observations } & 80,031 & 45,018 & 35,013 & 80,031 & 45,018 & 35,013 \\ \text { Adj. R-squared } & 0.160 & 0.246 & 0.184 & 0.164 & 0.238 & 0.192\end{array}$

Panel C. TMA

IVTMA

$-0.002^{* *}-0.006^{* * *}-0.003^{* *}-0.004^{* * *}-0.004^{* *}-0.005^{* * *}$

$[-2.57] \quad[-8.88] \quad[-2.03] \quad[-5.05] \quad[-2.34] \quad[-7.62]$

Continued on next page

This article is protected by copyright. All rights reserved. 
Table A6 - continued from previous page

\begin{tabular}{lcccccc}
\hline & $(\mathbf{1})$ & $\mathbf{( 2 )}$ & $\mathbf{( 3 )}$ & $\mathbf{( 4 )}$ & $\mathbf{( 5 )}$ & $\mathbf{( 6 )}$ \\
& Inef1 & Und1 & Ovr1 & Inef2 & Und2 & Ovr2 \\
\hline \multirow{2}{*}{ Variables } & & & & & & \\
Control variables & Yes & Yes & Yes & Yes & Yes & Yes \\
Industry \& year fixed effects & Yes & Yes & Yes & Yes & Yes & Yes \\
Observations & 80,031 & 45,018 & 35,013 & 80,031 & 35,013 & 45,018 \\
Adj. R-squared & 0.160 & 0.248 & 0.184 & 0.165 & 0.192 & 0.239 \\
\hline
\end{tabular}

This article is protected by copyright. All rights reserved. 


\section{Table A7. How do motivated monitoring institutional investors mitigate firm over-investment?}

This table presents the second stage regressions of firm over-investment on the product of the predicted motivated monitoring institutional ownership and firm cash. The first stage regression is the same as the one reported in Panel A of Table A4. In Columns (1) and (3), the dependent variables are the firm over-investment proxy variable Ovr1, estimated by the historical panel regressions. In Columns (2) and (4), the dependent variables are the firm over-investment proxy variable Ovr2, estimated by the single panel regression. The independent variables of interest in the second stage regressions are the product of the predicted Tmi1 by the first stage regressions and Cash (IVTmi1*Cash) in Columns (1)-(2) and the product of the predicted Tmi1 by the first stage regressions and FCF (IVTmi1*FCF) in Columns (3)-(4). FCF1 (FCF2) is estimated by Equation (6) with the historical panel regressions (the single panel regression). Detailed definitions of all variables are described in Appendix A. Fama-French 48 industry and year fixed effects are controlled for in all regressions. The standard errors are clustered by firm. $t$-values are reported in brackets. $* * *, * *$, and $*$ denote statistical significance at the $1 \%, 5 \%$, and $10 \%$ level, respectively.

\begin{tabular}{|c|c|c|c|c|}
\hline Variables & $\begin{array}{c}(1) \\
\text { Ovr } 1\end{array}$ & $\begin{array}{c}\text { (2) } \\
\text { Ovr2 }\end{array}$ & $\begin{array}{c}\text { (3) } \\
\text { Ovr } 1\end{array}$ & $\begin{array}{c}(4) \\
\text { Ovr } 2\end{array}$ \\
\hline IVTmi1 & $\begin{array}{c}-0.106^{* *} \\
{[-2.02]}\end{array}$ & $\begin{array}{c}-0.106^{* *} \\
{[-2.07]}\end{array}$ & $\begin{array}{c}-0.128^{*} \\
{[-1.86]}\end{array}$ & $\begin{array}{c}-0.132^{*} \\
{[-1.82]}\end{array}$ \\
\hline IVTmi $1 *$ Cash & $\begin{array}{c}-0.130 * * * \\
{[-3.80]}\end{array}$ & $-0.120 * * *$ & & \\
\hline$I V T m i 1 * F C F 1$ & & & $\begin{array}{c}-0.264^{* *} \\
{[-2.06]}\end{array}$ & \\
\hline$F C F 1$ & & & $\begin{array}{c}0.128^{* * *} \\
{[5.09]}\end{array}$ & \\
\hline$I V T m i 1 * F C F 2$ & & & & $\begin{array}{c}-0.302^{* *} \\
{[-2.28]}\end{array}$ \\
\hline$F C F 2$ & & & & $\begin{array}{c}0.124^{* * *} \\
{[4.66]}\end{array}$ \\
\hline Cash & $\begin{array}{c}0.025^{* * *} \\
{[5.67]}\end{array}$ & $\begin{array}{c}0.025^{* * *} \\
{[5.90]}\end{array}$ & $\begin{array}{c}0.013^{* *} \\
{[2.00]}\end{array}$ & $\begin{array}{c}0.011^{*} \\
{[1.73]}\end{array}$ \\
\hline$M T B$ & $\begin{array}{c}0.011^{* * *} \\
{[9.40]}\end{array}$ & $\begin{array}{c}0.011^{* * *} \\
{[9.07]}\end{array}$ & $\begin{array}{c}0.008^{* * * *} \\
{[4.85]}\end{array}$ & $\begin{array}{c}0.008^{* * *} \\
{[4.57]}\end{array}$ \\
\hline Leverage & $\begin{array}{c}0.016^{* * *} \\
{[4.62]}\end{array}$ & $\begin{array}{c}0.007^{* *} \\
{[2.16]}\end{array}$ & $\begin{array}{c}0.013^{* * * *} \\
{[3.22]}\end{array}$ & $\begin{array}{l}0.007 \\
{[1.61]}\end{array}$ \\
\hline Size & $\begin{array}{c}-0.006^{* * * *} \\
{[-3.05]}\end{array}$ & $\begin{array}{c}-0.006^{* * *} \\
{[-2.84]}\end{array}$ & $\begin{array}{c}-0.005^{* *} \\
{[-1.98]}\end{array}$ & $\begin{array}{c}-0.005^{*} \\
{[-1.82]}\end{array}$ \\
\hline Tangibility & $\begin{array}{c}0.015^{* * *} * \\
{[2.66]}\end{array}$ & $\begin{array}{c}0.012^{* *} \\
{[2.09]}\end{array}$ & $\begin{array}{c}0.022^{* * * *} \\
{[3.16]}\end{array}$ & $\begin{array}{c}0.016^{* *} \\
{[2.23]}\end{array}$ \\
\hline Age & $\begin{array}{c}-0.002^{* *} \\
{[-2.09]}\end{array}$ & $\begin{array}{c}-0.009 * * * \\
{[-8.69]}\end{array}$ & $\begin{array}{c}-0.003^{* *} \\
{[-2.14]}\end{array}$ & $\begin{array}{c}-0.008 * * * \\
{[-6.32]}\end{array}$ \\
\hline Constant & $\begin{array}{c}0.132^{* * *} \\
{[11.14]}\end{array}$ & $\begin{array}{c}0.128^{* * *} \\
{[11.31]}\end{array}$ & $\begin{array}{c}0.131^{* * * *} \\
{[8.14]}\end{array}$ & $\begin{array}{c}0.131^{* * * *} \\
{[7.97]}\end{array}$ \\
\hline Observatic & 35,013 & 35,013 & 19,333 & 17,529 \\
\hline Adj. R-squal & 0.185 & 0.192 & 0.134 & 0.144 \\
\hline Industry fixed effects & Yes & Yes & Yes & Yes \\
\hline Year fixed effects & Yes & $\begin{array}{c}\text { Yes } \\
\text { ts re }\end{array}$ & Yes & Yes \\
\hline
\end{tabular}




\section{Table A8. How does motivated monitoring by institutional investors mitigate firm under-investment?}

This table presents the second stage regressions of firm under-investment on the product of the predicted motivated institutional ownership and the variables proxy for firm managers' career concern. The first stage regression is the same as the one in Panel A of Table A4. In Columns (1) and (3), the dependent variables are the firm under-investment proxy variable $U n d 1$, estimated by the historical panel regressions. In Columns (2) and (4), the dependent variables are the firm under-investment proxy variable Und2, estimated by the panel regressions. In Columns (1) and (2), the independent variable of interest is the product of the predicted Tmi1 by the first stage regressions and Competition (IVTmi1 * Competition). In Columns (3) and (4), the independent variable of interest is the product of the predicted Tmi1 by the first stage regressions and $G$-index $(I V T m i 1 * G I n d e x)$. Detailed definitions of all variables are described in Appendix A. Fama-French 48 industry and year fixed effects are controlled for in all regressions. The standard errors are clustered by firm. t-values are reported in brackets. $* * *, * *$, and $*$ denote statistical significance at the $1 \%, 5 \%$, and $10 \%$ level, respectively.

\begin{tabular}{|c|c|c|c|c|}
\hline Variables & $\begin{array}{c}(\mathbf{1}) \\
U n d 1\end{array}$ & $\begin{array}{c}(\mathbf{2}) \\
U n d 2\end{array}$ & $\begin{array}{c}(3) \\
U n d 1\end{array}$ & $\begin{array}{c}(4) \\
U n d 2\end{array}$ \\
\hline IVTmi1 & $\begin{array}{l}-0.029 \\
{[-1.15]}\end{array}$ & $\begin{array}{l}-0.033 \\
{[-1.28]}\end{array}$ & $\begin{array}{c}-0.116^{* *} \\
{[-2.00]}\end{array}$ & $\begin{array}{c}-0.119 * * \\
{[-1.99]}\end{array}$ \\
\hline IVTmi $1 *$ Competition & $\begin{array}{c}-0.059^{* *} \\
{[-2.29]}\end{array}$ & $\begin{array}{c}-0.062^{* *} \\
{[-2.34]}\end{array}$ & & \\
\hline Competition & $\begin{array}{c}0.035^{* * *} \\
{[4.94]}\end{array}$ & $\begin{array}{c}0.034^{* * *} \\
{[4.65]}\end{array}$ & & \\
\hline IVTmi $1 *$ GIndex & & & $\begin{array}{c}0.008^{*} \\
{[1.65]}\end{array}$ & $\begin{array}{c}0.008^{*} \\
{[1.80]}\end{array}$ \\
\hline G-index & & & $\begin{array}{c}-0.002^{* *} \\
{[-2.01]}\end{array}$ & $\begin{array}{c}-0.002^{* *} \\
{[-2.13]}\end{array}$ \\
\hline$M T B$ & $\begin{array}{c}-0.001 * * * \\
{[-2.83]}\end{array}$ & $\begin{array}{c}-0.001^{* *} \\
{[-2.17]}\end{array}$ & $\begin{array}{l}0.000 \\
{[0.23]}\end{array}$ & $\begin{array}{l}0.001 \\
{[0.64]}\end{array}$ \\
\hline Leverage & $\begin{array}{c}-0.032 * * * \\
{[-23.57]}\end{array}$ & $\begin{array}{c}-0.027 * * * \\
{[-18.32]}\end{array}$ & $\begin{array}{c}-0.029 * * * \\
{[-7.51]}\end{array}$ & $\begin{array}{c}-0.015^{* * *} \\
{[-3.68]}\end{array}$ \\
\hline Cash & $\begin{array}{c}0.016^{* * *} \\
{[10.03]}\end{array}$ & $\begin{array}{c}0.013^{* * *} \\
{[7.70]}\end{array}$ & $\begin{array}{l}0.007 \\
{[1.40]}\end{array}$ & $\begin{array}{l}0.006 \\
{[1.20]}\end{array}$ \\
\hline Size & $\begin{array}{c}-0.004^{* * *} \\
{[-6.15]}\end{array}$ & $\begin{array}{c}-0.005^{* * * *} \\
{[-6.57]}\end{array}$ & $\begin{array}{c}-0.007 * * * \\
{[-3.87]}\end{array}$ & $\begin{array}{c}-0.008^{* * *} \\
{[-4.21]}\end{array}$ \\
\hline Tangibility & $\begin{array}{c}0.012^{* * *} \\
{[4.06]}\end{array}$ & $\begin{array}{c}0.011^{* * *} \\
{[3.79]}\end{array}$ & $\begin{array}{c}0.021^{* * *} \\
{[2.66]}\end{array}$ & $\begin{array}{c}0.023^{* * *} \\
{[2.87]}\end{array}$ \\
\hline Age & $\begin{array}{c}-0.001^{* *} \\
{[-2.52]}\end{array}$ & $\begin{array}{c}0.006^{* * *} \\
{[13.55]}\end{array}$ & $\begin{array}{c}-0.007 * * * \\
{[-7.55]}\end{array}$ & $\begin{array}{c}0.003^{* * *} \\
{[3.46]}\end{array}$ \\
\hline Constant & $\begin{array}{c}0.047^{* * *} \\
{[6.39]}\end{array}$ & $\begin{array}{c}0.051^{* * *} \\
{[6.90]}\end{array}$ & $\begin{array}{c}0.136^{* * *} \\
{[10.97]}\end{array}$ & $\begin{array}{c}0.141^{* * *} \\
{[11.53]}\end{array}$ \\
\hline Observations & 47,445 & 47,445 & 3,082 & 3,082 \\
\hline R-squared & 0.198 & 0.181 & 0.251 & 0.265 \\
\hline Industry fixed effects & Yes & Yes & Yes & Yes \\
\hline Year fixed effects & Yes & Yes & Yes & Yes \\
\hline
\end{tabular}

This article is protected by copyright. All rights reserved. 


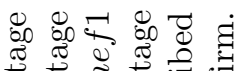

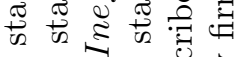

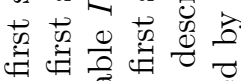

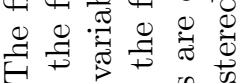

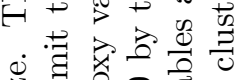

क

$\infty$ का है:

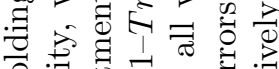

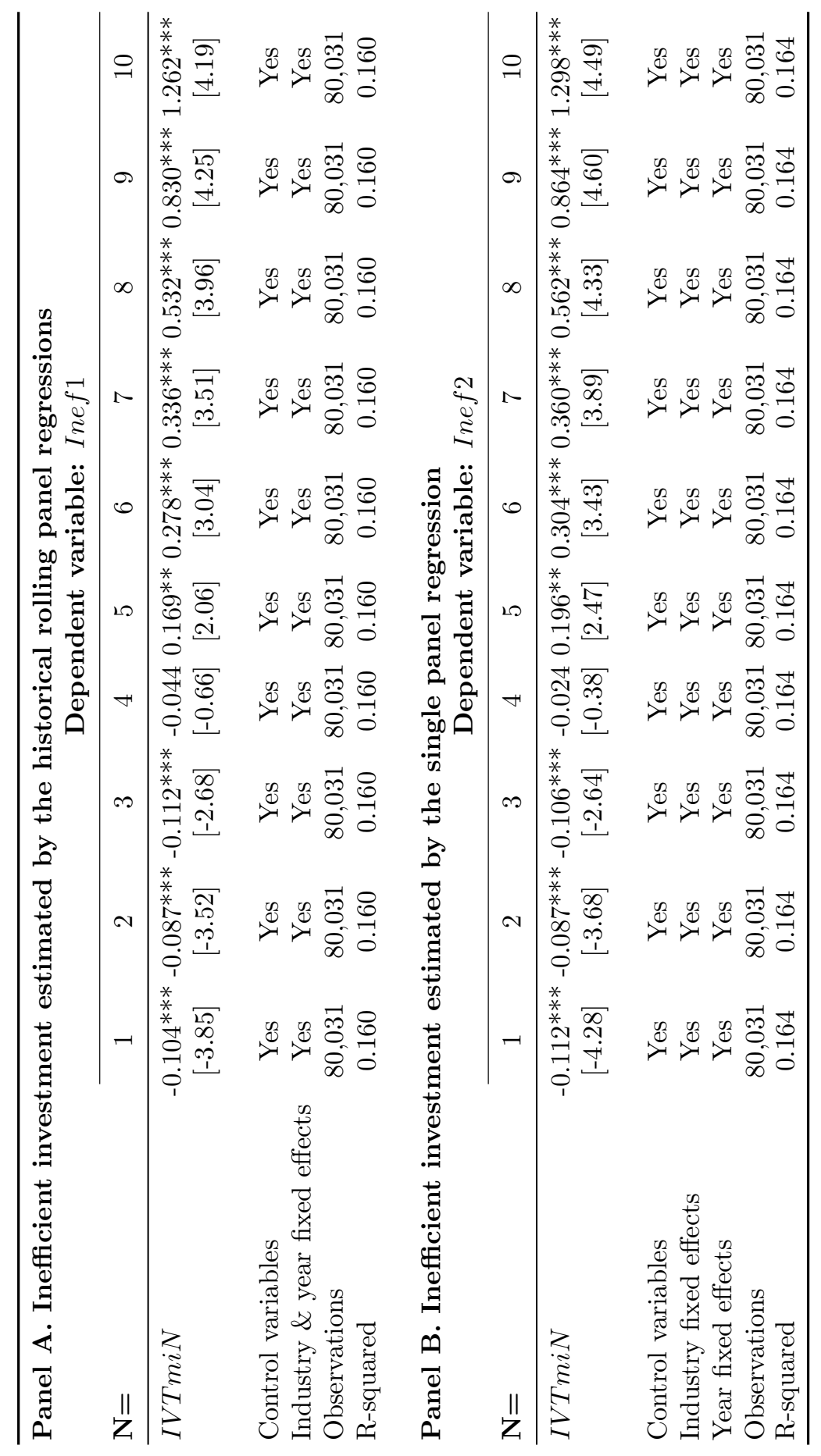

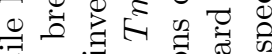

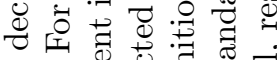

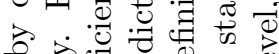

进 0

$\exists . \exists$

进

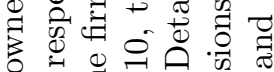

డี

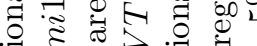

타조

औ

F

○

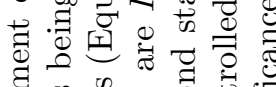

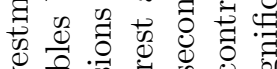

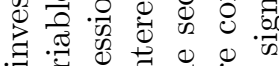

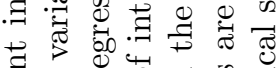

궁

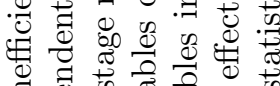

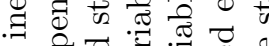

घ

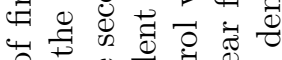

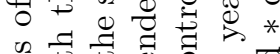

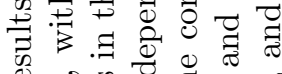

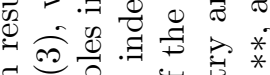

:

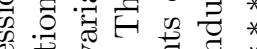

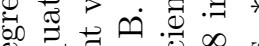

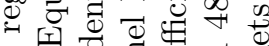

os

施造.

\&

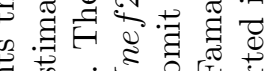

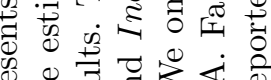

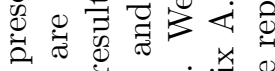

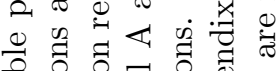

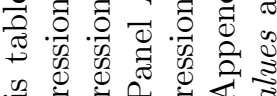

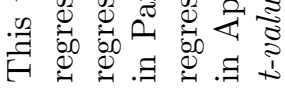

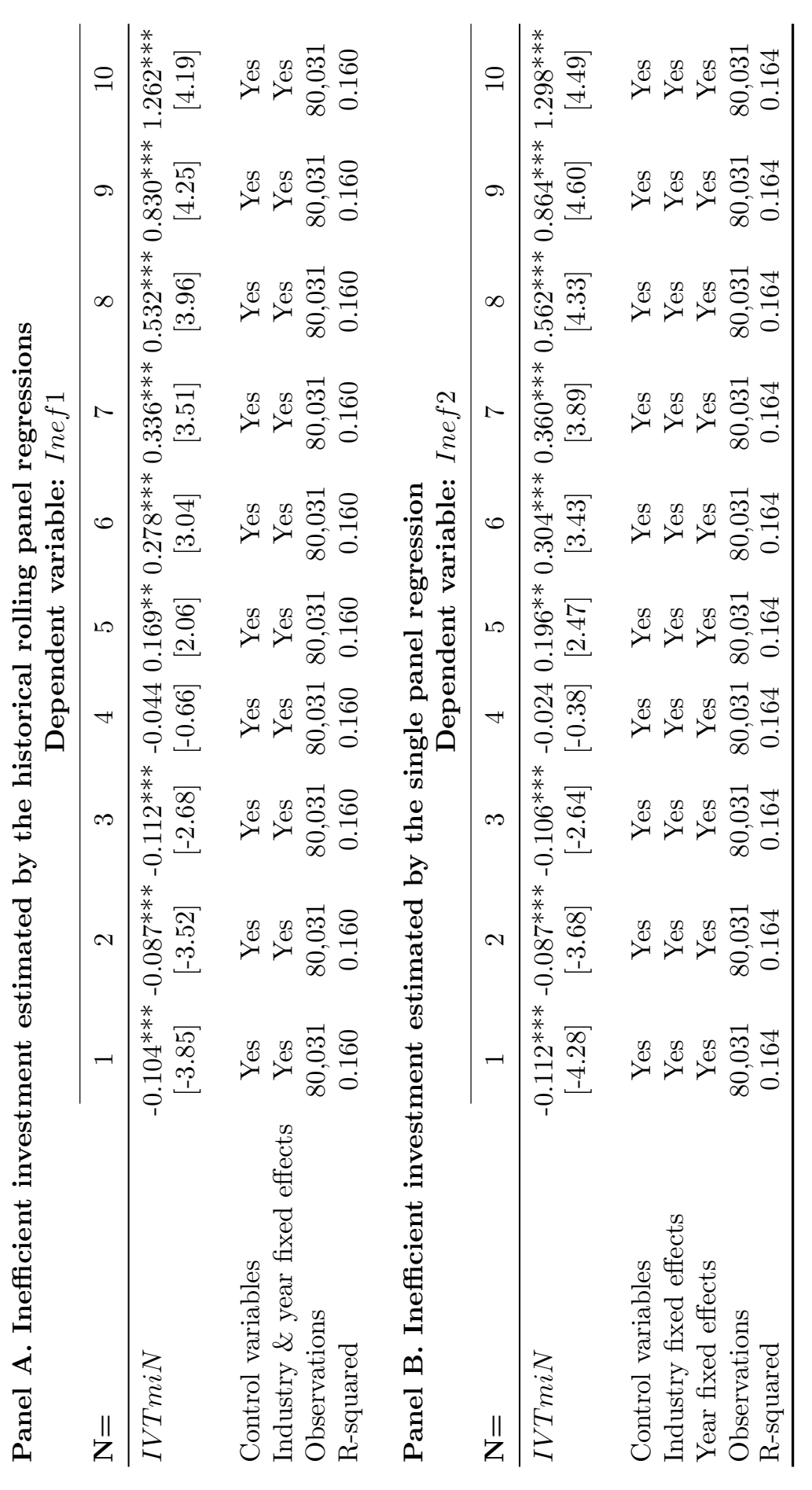

This article is protected by copyright. All rights reserved. 


\section{Dr Yeqin Zeng:}

Dr Yeqin Zeng is an Associate professor at Durham Business School. He has a Ph.D. (2013) in Finance from the Foster School of Business, the University of Washington. Before joining Durham University Business School in 2018, he was an Assistant Professor in Finance at ICMA Centre, Henley Business School. His main research interests are in empirical corporate finance and asset pricing with an emphasis on financial institutions and their interactions with both financial markets and corporations. He has published papers in journals such as Journal of Corporate Finance, European Financial Management, International Review of Financial Analysis, Asia-Pacific Journal of Accounting \& Economics, International Review of Economics and Finance.

\section{Professor Charles Ward:}

Professor Charles Ward is an Emeritus Professor of Property Investment and Finance at ICMA Centre, Henley Business School, University of Reading. He has held university posts in Lancaster, Stirling and Reading and has an economics degree from Cambridge, an M.A. in Finance from Exeter, and a Ph.D. from Reading. Before moving to the ICMA Centre, he was Professor of Property Investment and Finance in the School of Real Estate and Planning. His previous post was Professor of Accounting and Finance at Stirling University. His research spans a wide range of investment, finance, accounting and real estate and has been published in many journals including the Journal of Financial and Quantitative Analysis, Journal of Business Finance and Accounting, Oxford Bulletin of Economics and Statistics, Journal of Industrial Economics, Journal of Banking and Finance, Journal of Portfolio Management, and Real Estate Economics.

\section{Dr Chao Yin:}

Dr Chao Yin is an Assistant Professor in finance at the ICMA Centre, Henley Business School, University of Reading. His research interests include empirical corporate finance, corporate governance, and asset pricing. His current projects focus on the role of institutional investors in influencing corporate decision-making. He holds a Ph.D. in finance from ICMA centre at University of Reading (2018). His research has been published in various finance journals such as: Journal of Corporate Finance, Interhational Review of Financial Analysis, Journal of International Financial Market, institution and money.

This article is protected by copyright. All rights reserved. 